\title{
Transcriptomic analysis of Sorghum bicolor responding to combined heat and drought stress
}

\author{
Stephanie M Johnson ${ }^{1 *}$, Fei-Ling Lim² ${ }^{2}$ Aliza Finkler ${ }^{3}$, Hillel Fromm${ }^{3}$, Antoni R Slabas ${ }^{1}$ and Marc R Knight ${ }^{1}$
}

\begin{abstract}
Background: Abiotic stresses which include drought and heat are amongst the main limiting factors for plant growth and crop productivity. In the field, these stress types are rarely presented individually and plants are often subjected to a combination of stress types. Sorghum bicolor is a cereal crop which is grown in arid and semi-arid regions and is particularly well adapted to the hot and dry conditions in which it originates and is now grown as a crop. In order to better understand the mechanisms underlying combined stress tolerance in this important crop, we have used microarrays to investigate the transcriptional response of Sorghum subjected to heat and drought stresses imposed both individually and in combination.

Results: Microarrays consisting of 28585 gene probes identified gene expression changes equating to $\sim 4 \%$ and $18 \%$ of genes on the chip following drought and heat stresses respectively. In response to combined stress $\sim 20 \%$ of probes were differentially expressed. Whilst many of these transcript changes were in common with those changed in response to heat or drought alone, the levels of 2043 specific transcripts (representing $7 \%$ of all gene probes) were found to only be changed following the combined stress treatment. Ontological analysis of these 'unique' transcripts identified a potential role for specific transcription factors including MYB78 and ATAF1, chaperones including unique heat shock proteins (HSPs) and metabolic pathways including polyamine biosynthesis in the Sorghum combined stress response.

Conclusions: These results show evidence for both cross-talk and specificity in the Sorghum response to combined heat and drought stress. It is clear that some aspects of the combined stress response are unique compared to those of individual stresses. A functional characterization of the genes and pathways identified here could lead to new targets for the enhancement of plant stress tolerance, which will be particularly important in the face of climate change and the increasing prevalence of these abiotic stress types.
\end{abstract}

Keywords: Combined stress, Drought, Heat, Microarray, Sorghum, Transcriptomics

\section{Background}

Adverse environmental conditions result in substantial losses to agricultural food production worldwide. In particular, abiotic stresses, which include drought, heat and salinity, are amongst the biggest constraints on crop productivity [1,2]. These types of abiotic stress are, however, rarely presented individually and crops are often subjected to simultaneous adverse conditions, particularly in arid and semi-arid regions of the world [3]. Such combined stress has been shown in Sorghum, wheat and other grass crops to have an even greater detrimental impact on plant

\footnotetext{
* Correspondence: Stephanie.johnson@durham.ac.uk

'Durham Centre for Crop Improvement Technology, School of Biological and Biomedical Sciences, Durham University, South Road, DH1 3LE Durham, UK Full list of author information is available at the end of the article
}

productivity than when each stress is imposed individually [4-6]. Land area affected by combined stress is likely to increase given the anticipated climate changes [7]. The co-incidence of heat and drought stress is therefore likely to become an increasingly common scenario in the future.

As a result of their sessile nature, when faced with adverse conditions, plants alter their biochemical and molecular machinery in order to adapt to the change in their environment. Following the perception of the stress, a signal is relayed to the nucleus via complex cellular signalling networks involving second messengers such as reactive oxygen intermediates (ROIs) and calcium, calcium-associated proteins and kinase cascades such as mitogen-activated protein (MAP) kinase cascades [8-11]. This leads to the 
activation of transcriptional pathways which in turn may lead to changes in the flow of metabolites, induction of stress tolerance genes and physiological changes associated with protection from cellular damage [8-11]. Examples of stress tolerance genes include molecular chaperones such as Late Embryogenesis Abundant (LEA) proteins and Heat Shock Proteins (HSPs) which act to protect proteins and membranes [1]. The changes in response to stress at the transcriptomic level must be modulated both rapidly and with specificity to the particular stress encountered and are of key importance for a plant response which is tailored to its environment.

An analysis of changes at the transcript level can be used to identify new signaling proteins and metabolic processes which are important for providing stress tolerance to plants. The transcriptional response to heat or drought stresses imposed on their own has been extensively studied in a number of plant species [12-15]. These studies have identified particular processes required for stress tolerance. Interestingly, it has been found that a combination of drought and heat stress in Arabidopsis and tobacco results in a unique transcriptional response which cannot simply be extrapolated from the effect of each stress imposed individually [16-18]. Plants therefore have novel responses when presented with combined stress.

Sorghum (Sorghum bicolor L. Moench.) is a grain crop which is grown in the arid and semi-arid regions of South Africa, Australia, India and America. It is grown primarily as a food source and is the dietary staple for more than 500 million people [19]. Given that Sorghum thrives under conditions of low water availability and high temperatures it is an excellent model for the study of transcriptomic changes induced to enable tolerance to drought and heat stress. A wealth of research has been performed on Sorghum physiology in order to select for agriculturally beneficial traits, however, until recently molecular characterization has been relatively limited. This has been facilitated in recent years by the sequencing of the Sorghum genome [20]. The transcriptomic response of Sorghum to osmotic stress, induced by PEG, has been reported [21,22] however there are no published reports using bona fide droughttreated samples. No transcriptomic analyses of heat responses or combined heat and drought responses in Sorghum have yet been reported.

Given the previously observed unique transcriptional response to combined stress in Arabidopsis and tobacco, we have investigated changes in gene expression which occur following a similar treatment in Sorghum. The aim of this was to identify important processes/responses required for combined stress tolerance in this important crop particularly adapted to hot and arid environments, as it might offer insight not gained from other species. We have used custom-designed microarrays containing 28585 gene probes based on the latest genome annotations at the time of printing. We have identified sets of genes which are differentially expressed in response to each treatment type, as well as demonstrating that there is specificity of gene expression; specific genes being upand down-regulated only in response to combined (but not individual) stress. Analysis of these genes suggests that specific processes e.g. polyamine synthesis might be involved in tolerance to combined heat and drought stress in Sorghum. This study will be useful for not only improving our understanding of basic stress tolerance mechanisms but also in the development of new stress tolerant Sorghum cultivars.

\section{Results}

Transcriptomic analysis of Sorghum subjected to drought, heat and combined drought and heat stress

To investigate the changes in gene expression which occur in Sorghum subjected to heat and drought stresses either on their own, or in combination, we carried out transcriptomic analyses using DNA microarrays (Agilent Technologies Ltd) containing 28585 unique gene probes. Drought stress was administered to seedlings by withdrawing water from 14 days after sowing (DAS) whilst the remaining (control) plants were well-watered. Heat shock was carried out by subjecting the seedlings to $50^{\circ} \mathrm{C}$ for 3 hours, compared to a control treatment of $28^{\circ} \mathrm{C}$. The heat shock was conducted at the point at which $\mathrm{F}_{\mathrm{v}} / \mathrm{F}_{\mathrm{m}}$, which gives an indication of photosynthetic efficiency $[23,24]$, first started to significantly drop in the drought stressed plants, with respect to the well-watered controls. This was at around 3 days following water withdrawal (Additional file 1: Figure S1). In this way we were able to ensure that the drought stressed plants were experiencing bona fide stress when the combined treatment was executed.

\section{Gene expression responses to drought}

As shown in Figure 1966 Sorghum transcripts were upregulated and 224 were down-regulated by greater than 2fold following drought stress only when compared to the untreated plants, equating to approximately $4 \%$ of the genes on the chip. Amongst the most highly elevated transcripts are those encoding Late Embryogenesis Abundant (LEA) proteins. Other highly elevated genes include P5CS2, which is involved in the metabolism of the compatible solute proline [25] and HKT1, a sodium ion transmembrane transporter involved in maintaining cellular $\mathrm{Na}^{+}$homeostasis [26] (Additional file 1: Table S1). Of the top 100 up and down regulated transcripts however, 15 encode proteins of unknown function (Table 1). In order to further explore the biological processes and molecular functions which are enriched within this (drought-regulated) gene set relative to the background genome, gene ontology (GO) analysis was carried out (Figure 2). In total, 92 GO 


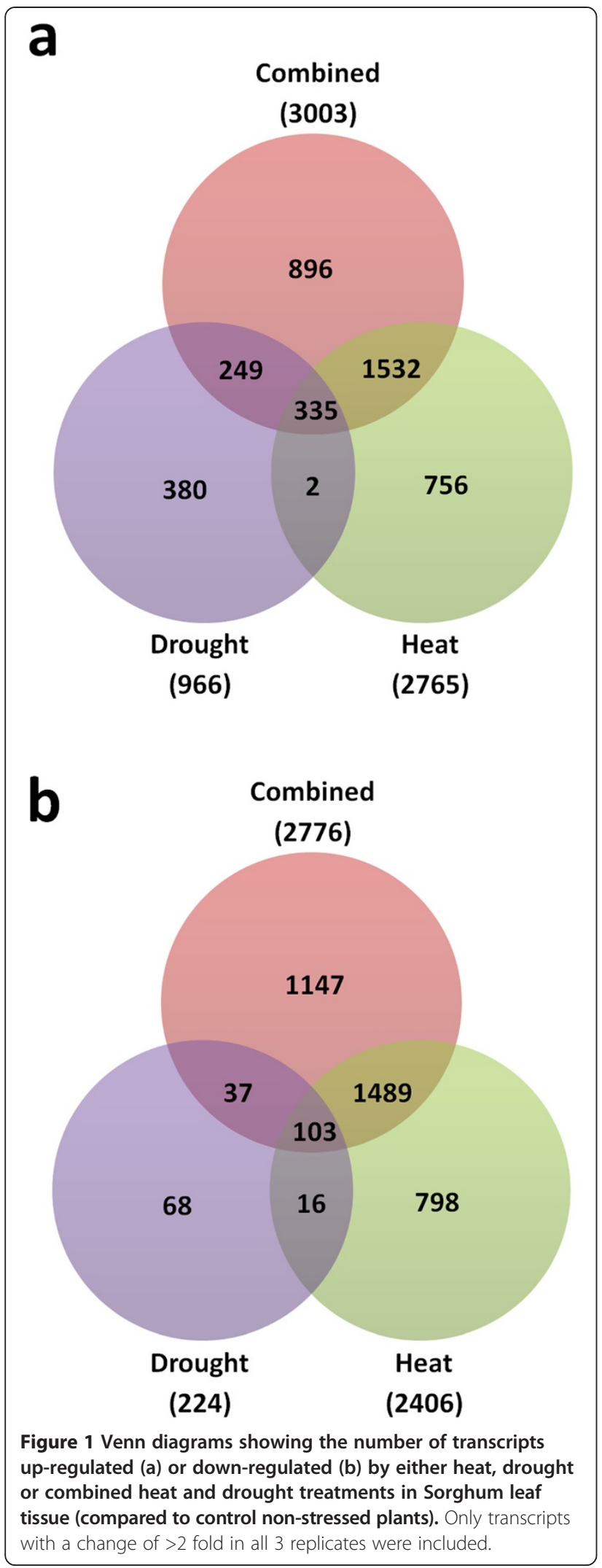

categories exhibited significant enrichment in the drought up-regulated genes based upon a corrected p-value cut-off of 0.05 (Additional file 1: Table S2). As would be expected, the analysis shows an enrichment of genes involved in response to stress and in particular response to water deprivation. Genes associated with response to $A B A$ are also enriched within the data set which is not surprising given the central role of $\mathrm{ABA}$ in the drought stress response [27]. Other examples of enriched GO categories include regulation of photosynthesis, fluid transport and amino acid metabolism (Figure 2a). Promoter motif analysis was carried out to identify promoter motifs which are enriched within the drought data set. As can be seen in Figure 3, the most highly represented promoter motif in the 966 drought up-regulated genes was similar to the abscisic acid response element (ABRE): (C/T)ACGTGTC.

Three hundred and eighty transcripts were found to be up-regulated exclusively in response to drought stress i.e. were not also up-regulated in response to heat, or heat and drought in combination (Figure 1a). This was validated by carrying out $\mathrm{qPCR}$ on selected genes and is exemplified by Sb01g021320 (Figure 4a). These 380 genes include examples associated with lipid transport such as a number of lipid transfer proteins (LTPs) and genes involved with the regulation of cell size such an expansin (see Additional file 1: Table S3 for full gene lists). Interestingly, 2 LEA genes were found to be up-regulated exclusively in response to drought, suggesting specific LEAs may have specific unique roles in response to different stress types.

Previous work carried out by Dugas, et al. [21], using next generation sequencing transcriptomic approaches, has identified differentially expressed transcripts in Sorghum leaves following osmotic stress imposed by PEG treatment. In order to determine whether there are differences in the Sorghum response to different types of osmotic stress i.e. PEG treatment compared to the gradual water loss imposed here, we compared the differentially expressed transcripts identified in both studies. Approximately one third of our drought-induced transcripts were in common with those identified by Dugas et al. (Figure 5). GO analysis of these overlapping genes shows an enrichment of genes associated with response to water deprivation, regulation of photosynthesis and response to ABA (Table 2). However, 902 and 807 transcripts were unique to either the PEG treatment or the water withdrawal treatment respectively. GO analysis of the genes unique to the PEG treatment shows an enrichment of genes associated with response to stress and response to reactive oxygen species (Table 3). However, GO analysis of the genes unique to the gradual water withdrawal, shows a strong enrichment of genes associated with wax biosynthesis (Table 4). Different processes therefore seem to be associated with the different stress types. 
Table 1 Top 100 genes differentially expressed in response to drought (based on average absolute fold change) compared to control unstressed plants

\begin{tabular}{|c|c|c|c|}
\hline SbID & Annotation & $\begin{array}{l}\text { Average fold } \\
\text { change (Abs) }\end{array}$ & Regulation \\
\hline Sb01g046000.1 & Unknown protein & 2900.8 & Up \\
\hline Sb03g029830.1 & Unknown protein & 1243.2 & Up \\
\hline Sb10g028640.2 & Unknown protein & 1074.9 & Up \\
\hline Sb07g021850.1 & Uknown protein & 1066.6 & Up \\
\hline Sb01g046490.1 & LEA protein & 924.5 & Up \\
\hline Sb09g027110.2 & unknown protein & 865.4 & Up \\
\hline Sb07g000520.1 & CYP71A25 & 829.8 & Up \\
\hline Sb09g027110.1 & LEA protein & 776.7 & Up \\
\hline Sb03g001130.1 & $\begin{array}{l}\text { AAA-type ATPase family } \\
\text { protein }\end{array}$ & 669.0 & Up \\
\hline Sb07g023010.1 & $\begin{array}{l}\text { AMY1 } \\
\text { (ALPHA-AMYLASE-LIKE) }\end{array}$ & 586.6 & Up \\
\hline Sb03g011090.1 & $\begin{array}{l}\text { ATECP63 (EMBRYONIC } \\
\text { CELL PROTEIN 63) }\end{array}$ & 570.9 & Up \\
\hline Sb06g004280.1 & Transketolase & 564.8 & Up \\
\hline Sb02g013190.1 & Unknown protein & 539.5 & Up \\
\hline Sb02g043300.1 & HB-3; transcription factor & 520.6 & Up \\
\hline Sb03g034280.1 & $\begin{array}{l}\text { ATNADP-ME1 (NADP-malic } \\
\text { enzyme 1) }\end{array}$ & 467.0 & Up \\
\hline Sb01g012640.1 & PAP85; nutrient reservoir & 447.1 & Up \\
\hline Sb07g003040.1 & Tyrosine decarboxylase & 444.5 & Up \\
\hline Sb03g032380.2 & Unknown protein & 407.1 & Up \\
\hline Sb03g043410.1 & Unknown protein & 385.5 & Up \\
\hline Sb09g021016.1 & $\begin{array}{l}\text { AP2 domain-containing } \\
\text { transcription factor, } \\
\text { putative }\end{array}$ & 383.3 & Up \\
\hline Sb01g009730.1 & Unknown protein & 367.4 & Up \\
\hline Sb08g023230.1 & Unknown protein & 367.4 & Up \\
\hline Sb07g003010.1 & Tyrosine decarboxylase & 349.8 & Up \\
\hline Sb04g031810.1 & Unknown protein & 348.0 & Up \\
\hline Sb01g037560.1 & $\begin{array}{l}\text { Mitochondrial import inner } \\
\text { membrane translocase } \\
\text { subunit Tim17/Tim22/ } \\
\text { Tim23 family protein }\end{array}$ & 308.4 & Up \\
\hline Sb04g009130.1 & $\begin{array}{l}\text { LEA domain-containing } \\
\text { protein }\end{array}$ & 306.7 & Up \\
\hline Sb01g038670.1 & $\begin{array}{l}\text { Hydrophobic protein, } \\
\text { putative }\end{array}$ & 280.8 & Up \\
\hline Sb01g037560.2 & Unknown protein & 278.9 & Up \\
\hline Sb03g036980.1 & $\begin{array}{l}\text { DC1 domain-containing } \\
\text { protein }\end{array}$ & 272.5 & Up \\
\hline Sb04g023920.1 & $\begin{array}{l}\text { UGT85A2 (UDP-glucosyl } \\
\text { transferase 85A2) }\end{array}$ & 267.0 & Up \\
\hline Sb09g018420.1 & $\begin{array}{l}\text { RAB18 } \\
\text { (RESPONSIVE TO ABA 18) }\end{array}$ & 264.6 & Up \\
\hline Sb01g050670.1 & OLEO1 (OLEOSIN 1) & 251.3 & Up \\
\hline Sb08g005220.1 & Unknown protein & 223.5 & Up \\
\hline
\end{tabular}

Table 1 Top 100 genes differentially expressed in response to drought (based on average absolute fold change) compared to control unstressed plants (Continued)

\begin{tabular}{llll}
\hline Sb10g003700.1 & XERO1 (DEHYDRIN XERO 1) & 217.0 & Up \\
Sb05g003200.1 & Unknown protein & 209.3 & Up \\
Sb04g033380.1 & HB-7 (HOMEOBOX 7) & 192.7 & Up \\
Sb02g006320.1 & SIP2 (seed imbibition 2) & 190.0 & Up \\
Sb04g021000.1 & SAG29 (SENESCENCE- & 187.4 & Up \\
& ASSOCIATED PROTEIN 29) & & \\
Sb03g028870.1 & KING1 (SNF1-RELATED & 185.3 & Up \\
& PROTEIN KINASE & &
\end{tabular}
REGULATORY SUBUNIT GAMMA 1)

Sb03g029890.1 PP2CA (PROTEIN PHOSPHATASE 2CA)

Sb07g026340.1 F-box family protein

184.4 Up

Sb02g034590.1 Aconitate hydratase

$179.9 \quad$ Up

$177.5 \quad U p$

Sb03g030050.1 GBF3 (G-BOX BINDING $172.8 \quad$ Up

Sb06g027900.1 HKT1 (HIGH-AFFINITY $155.9 \quad$ Up $K+$ TRANSPORTER 1)

Sb10g028640.1 WIN2 (HOPW1-1INTERACTING 2)

Sb05g016880.1 unknown protein

Sb06g001720.1 HAB1 (HOMOLOGY TO $A B \mid 1)$

Sb07g015410.1 LEA protein

Sb06g034080.1 phosphatidylinositol-4phosphate 5-kinase family protein

Sb07g021840.1 unknown protein

$130.5 \quad$ Up

Sb03g032230.1 S-adenosyl-L-methionine: carboxyl methyltransferase family protein

Sb05g005480.1 CYP71B2

$129.0 \quad U p$ (CYTOCHROME P450 71B2)

Sb04g032890.1 Unknown protein $128.1 \quad$ Up

Sb04g008300.1 HSFC1

Sb06g033420.1 Unknown protein

127.0

Sb04g037900.1 DNA-binding family

118.5

114.9

Sb03g007420.1 Unknown protein

113.3

Sb04g017790.1 LEA protein

105.7

Sb03g012500.1 Mitochondrial import inner

105.6 membrane translocase subunit Tim17/Tim22/ Tim23 family protein

Sb03g030050.2 Unknown protein

$100.8 \quad$ Up

Sb08g009120.1 Unknown protein

Sb03g036040.1 HMT2 (HOMOCYSTEINE

99.0

93.5 METHYLTRANSFERASE 2)

Sb01g017695.1 LT165 (LOW-TEMPERATURE- 91.2 INDUCED 65)
Up

Up

P

p

p

p

p

Up

p

Up

Up

Up

Up

Up

up

Up

\section{p}

up

p

Up

Up

Up

Up

Up
Up
Up
Up

Up 
Table 1 Top 100 genes differentially expressed in response to drought (based on average absolute fold change) compared to control unstressed plants (Continued)

\begin{tabular}{|c|c|c|c|}
\hline Sb01g036790.1 & $\begin{array}{l}\text { ECP63 (EMBRYONIC CELL } \\
\text { PROTEIN 63) }\end{array}$ & 90.3 & Up \\
\hline Sb06g019610.1 & $\begin{array}{l}\text { PFK2 } \\
\text { (PHOSPHOFRUCTOKINASE 2) }\end{array}$ & 89.6 & Up \\
\hline Sb10g002440.1 & Unknown protein & 89.2 & Up \\
\hline Sb07g003720.1 & $\begin{array}{l}\text { TT7 } \\
\text { (TRANSPARENT TESTA 7) }\end{array}$ & 89.2 & Up \\
\hline Sb01g039890.1 & Protein phosphatase $2 \mathrm{C}$ & 88.0 & Up \\
\hline Sb04g020543.1 & RXF12 & 86.6 & Up \\
\hline Sb09g023040.1 & $\begin{array}{l}\text { Phosphatidylethanolamine- } \\
\text { binding family protein }\end{array}$ & 86.4 & Up \\
\hline Sb02g004640.1 & Unknown protein & 85.4 & Up \\
\hline Sb10g000930.1 & $\begin{array}{l}\text { LEA groUp } 1 \\
\text { domain-containing protein }\end{array}$ & 85.2 & Up \\
\hline Sb06g025580.1 & unknown protein & 84.9 & Up \\
\hline Sb09g006220.1 & $\begin{array}{l}\text { basic helix-loop-helix } \\
\text { (bHLH) family protein }\end{array}$ & 84.6 & Up \\
\hline Sb01g043910.1 & $\begin{array}{l}\text { HB40 } \\
\text { (HOMEOBOX PROTEIN 40) }\end{array}$ & 82.8 & Up \\
\hline Sb02g004560.1 & Unknown protein & 82.6 & Up \\
\hline Sb06g020045.1 & $\begin{array}{l}\text { C2 domain-containing } \\
\text { protein }\end{array}$ & 80.2 & Up \\
\hline Sb06g027090.1 & $\begin{array}{l}\text { MLP423 } \\
\text { (MLP-LIKE PROTEIN 423) }\end{array}$ & 80.1 & Up \\
\hline Sb03g041320.1 & Unknown protein & 79.9 & Up \\
\hline Sb09g018630.1 & $\begin{array}{l}\text { ERF1-2 (EUKARYOTIC } \\
\text { RELEASE FACTOR 1-2) }\end{array}$ & 78.6 & Up \\
\hline Sb04g000620.1 & $\begin{array}{l}\text { BETAFRUCT4; beta- } \\
\text { fructofuranosidase }\end{array}$ & 77.7 & Up \\
\hline Sb06g025570.1 & Unknown protein & 76.2 & Up \\
\hline Sb02g010080.1 & $\begin{array}{l}\text { AWPM-19-like membrane } \\
\text { family protein }\end{array}$ & 74.1 & Up \\
\hline Sb06g025450.1 & Unknown protein & 72.6 & Up \\
\hline Sb03g032380.1 & LEA protein & 72.1 & Up \\
\hline Sb09g024255.1 & EDL3 (EID1-like 3) & 71.2 & Up \\
\hline Sb02g025810.1 & Subtilase family protein & 70.9 & Up \\
\hline Sb03g006690.1 & Unknown protein & 70.6 & Up \\
\hline Sb01g030345.1 & $\begin{array}{l}\text { Plant EC metallothionein- } \\
\text { like family } 15 \text { protein }\end{array}$ & 70.3 & Up \\
\hline Sb04g016960.1 & Unknown protein & 69.8 & Up \\
\hline Sb03g039820.2 & Unknown protein & 69.1 & Up \\
\hline Sb10g008130.1 & FTSH6 (FTSH PROTEASE 6) & 66.3 & Up \\
\hline Sb01g005110.1 & SHY2 (SHORT HYPOCOTYL 2) & 66.3 & Up \\
\hline Sb03g039820.1 & $\begin{array}{l}\text { P5CS2 (DELTA 1- } \\
\text { PYRROLINE-5-CARBOXYL- } \\
\text { ATE SYNTHASE 2) }\end{array}$ & 64.4 & Up \\
\hline Sb06g033100.1 & Unknown protein & 63.9 & Up \\
\hline Sb03g013660.1 & Unknown protein & 63.1 & Up \\
\hline
\end{tabular}

Table 1 Top 100 genes differentially expressed in response to drought (based on average absolute fold change) compared to control unstressed plants (Continued)

\begin{tabular}{llcl}
\hline Sb01g048120.1 & $\begin{array}{l}\text { Transcription } \\
\text { activator-related }\end{array}$ & 60.3 & Up \\
Sb01g020830.1 & $\begin{array}{l}\text { Peroxidase, putative } \\
\text { Sb09g020240.1 }\end{array}$ & 59.5 & Up \\
& $\begin{array}{l}\text { proton-dependent } \\
\text { (POT) family protein }\end{array}$ & 59.3 & Up \\
Sb03g035570.1 & serine protease inhibitor & 58.9 & Up \\
\hline
\end{tabular}

\section{Gene expression responses to heat}

Following heat stress, 2765 Sorghum transcripts were up-regulated and 2406 down-regulated $(\sim 18 \%$ of the genes on the chip in total) (Figure 1 and Additional file 1: Table S4). The most enriched promoter motif in the 2765 heat up-regulated genes was found to be, CGCGCCCG which, whilst showing some similarity to CAMTA binding sites, was not identical to known promoter motifs. The second and fourth most enriched sequences, however, had consensuses containing the basic 5 bp heat shock element (HSE) motif, nGAAn (nTTCn in reverse complement) and overlapping with the full triple repeat HSE, nGAAnnTTCnnGAAn (Figure 3). As expected, amongst the transcripts most highly up-regulated in response to heat were a large number of genes encoding Heat Shock Proteins (HSPs) (23 of the top 100 gene changes) and Universal Stress Proteins (USPs) (Table 5). Some of these are unique to heat stress with 5 elevated only in response to this stress type (not expressed in response to heat and drought combined, or drought alone). These HSP genes are accompanied by the unique upregulation of 2 heat shock factors (HSFs) which are known to regulate the expression of HSPs (Wang et al., 2003). Genes which are up-regulated only by heat stress are represented by Sb02g038425 (Figure 4b). Other highly induced genes are associated with protection from oxidative stress and include ascorbate peroxidase 3 (see Additional file 1: Table S6 for full gene list). Gene ontology analysis of the heat up-regulated genes shows an enrichment of the following categories: response to heat, response to high light, response to ROI and protein folding (Additional file 1: Table S5). Enriched pathways which are in common with the drought stress response include response to ABA and lipid localization whilst other categories such as protein folding are only enriched in the heat gene set (Figure 2a and Additional file 1: Tables S2 and S5).

\section{Combined heat and drought control the expression of} distinct group of genes

Following the combined heat and drought stress 3003 transcripts were up-regulated and 2776 were down-regulated 


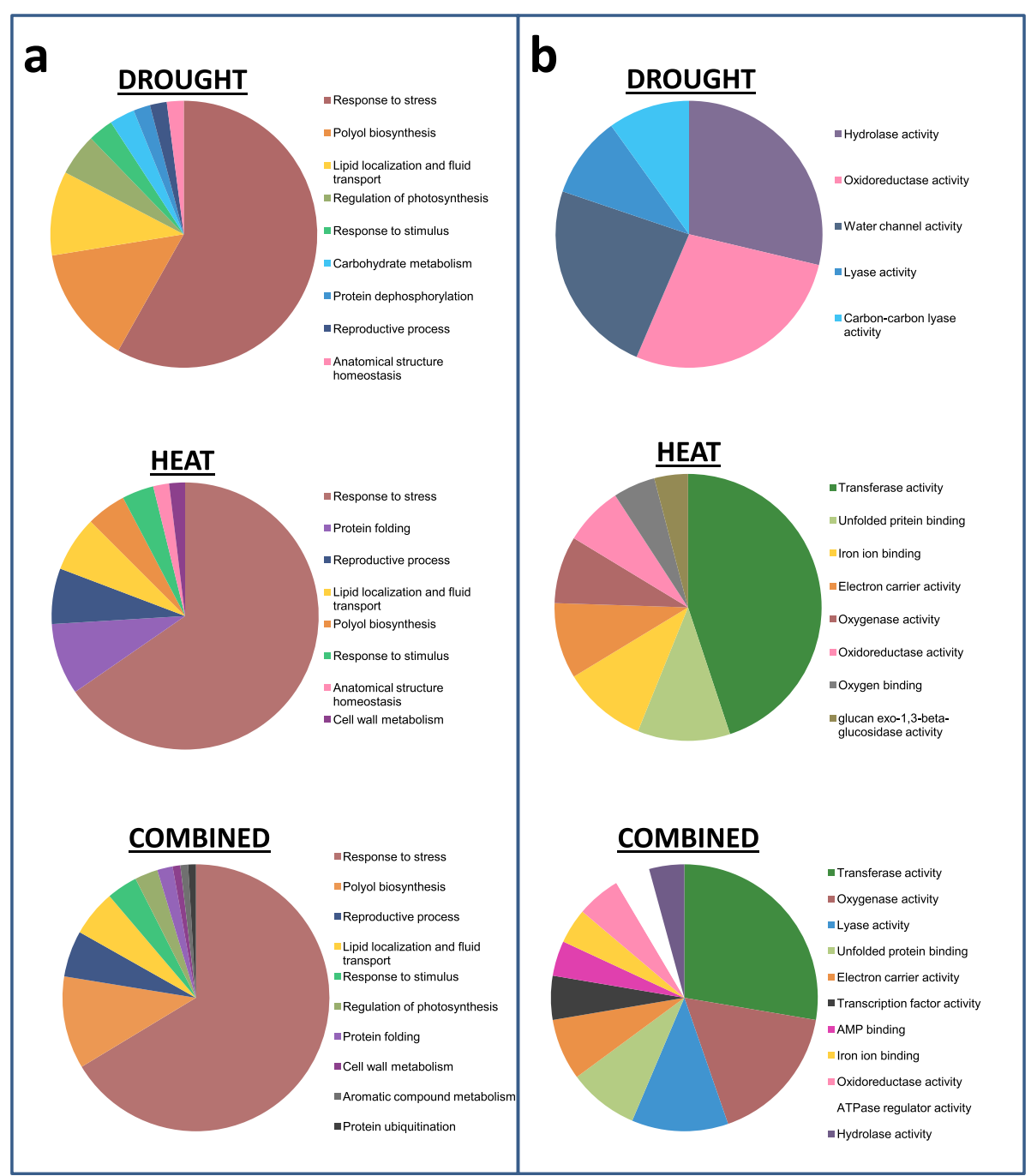

Figure 2 Pie charts showing summarised Gene Ontology (GO) analysis of the total gene sets responding to either drought, heat or combined drought and heat stress. (a) shows biological process $\mathrm{GO}$ terms and (b) shows molecular process GO terms. Only GO terms enriched with a $p$ value of $<0.05$ were selected and summarized using REVIGO (see methods). Detailed breakdowns of the ontologies are available in Additional file 1: Tables S2, S5 and S8.

( $\sim 20 \%$ of gene spots in total) compared to the untreated control. The top 100 gene changes are shown in Table 6 (see Additional file 1: Table S7 for full list). Out of this total of 5779 (both up and down) gene expression changes, a large proportion (60\%) were shared with the heat stress only response and $13 \%$ were shared with the response to drought (Figure 1). Despite this greater overlap with heat, none of the top 5 promoter motifs enriched in genes upregulated by combined heat and drought contained the basic 5 bp HSE. Indeed the most enriched motif was most similar to the ABRE, $(\mathrm{C} / \mathrm{T})$ ACGTGTC (Figure 3). Gene expression changes that were in common in the response to all 3 treatments totalled 438 (335 up-regulated, and 103 down-regulated).
These particular genes are associated with the general plant stress response and include heat shock proteins, senescence-associated genes (SAGs) and glutathione transferases (Additional file 1: Table S11). It is not surprising that many of the GO categories enriched following combined stress are in common with those enriched following drought or heat alone (Figure 2). For example, lipid localization and fluid transport, regulation of photosynthesis and protein folding are all enriched in the combined stress gene set (Additional file 1: Table S8). However, some ontological processes appear unique to the combined stress up-regulated transcripts. These include genes associated with protein ubiquitination and aromatic compound metabolism (Figure 2a). 


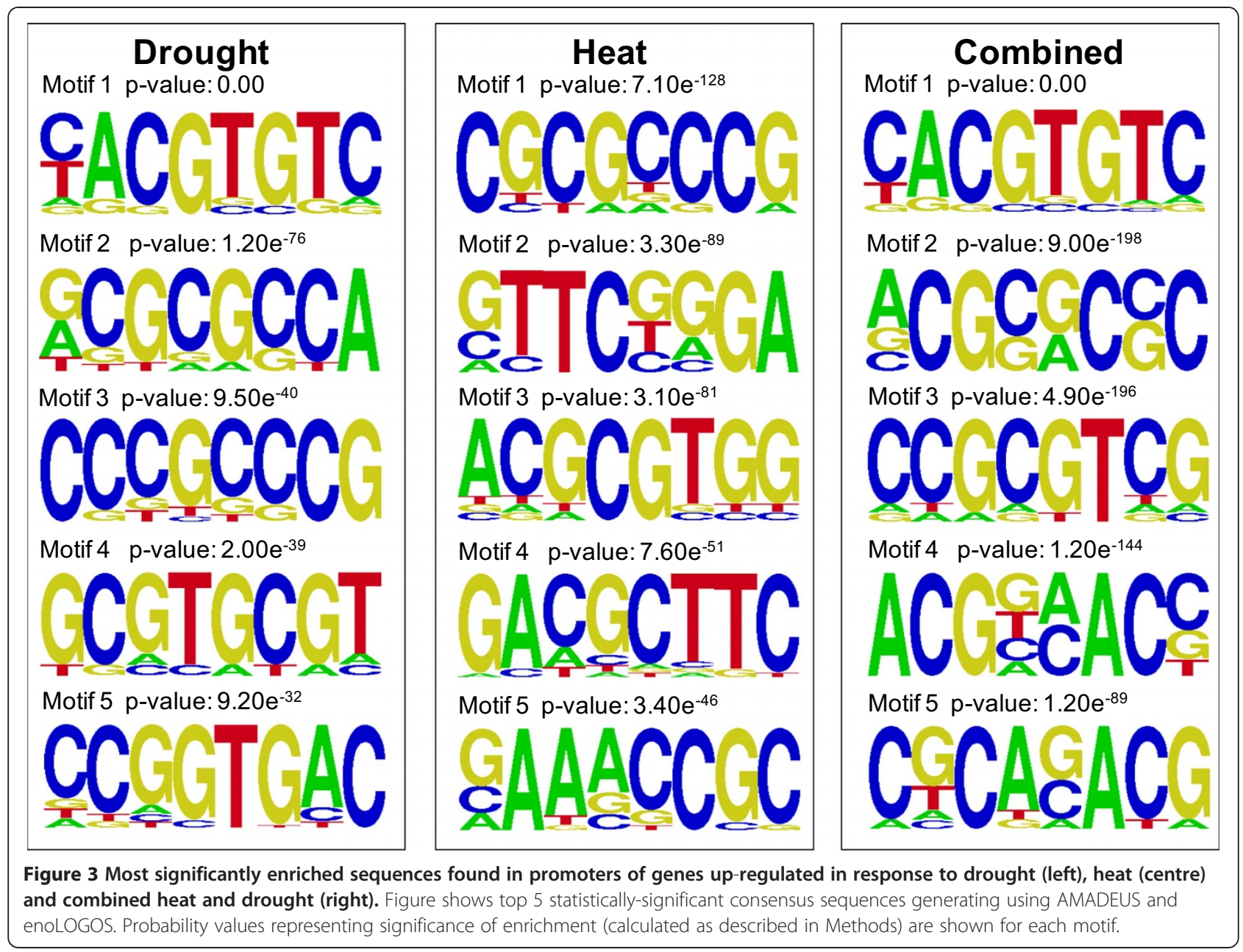

Identification of genes responding only when drought and heat occur simultaneously

Interestingly, a number of genes, 896 and 1147, were significantly up or down regulated, respectively, only in response to combined heat and drought stress (Figure 1). Again, the most enriched promoter motif in the 896 up-regulated genes was an ABRE-like motif, and there was no evidence of HSE-like motifs (Figure 6a). Genes uniquely elevated by combined stress, as exemplified by $S b 05 g 017950$ (Figure 4c) include a number of ion transporters. For example, the potassium transporters $A K T 1, A K T 2 / 3$ and $H A K 5$ were all (up to 8 -fold) and specifically up-regulated. As mentioned earlier there is also specificity in $L E A$ and $H S P$ expression with, in this case, 2 HSP and 3 LEA genes being uniquely up-regulated following combined stress. A number of genes encoding signalling proteins and transcription factors were up or down-regulated only by combined stress. These include ATAF1, MYB78 and WOX1 amongst others (Additional file 1: Table S9). Genes uniquely down-regulated by combined stress include the transcription factors MYB61 and BZIP61. In addition, there is specificity of calcium-binding proteins with the genes encoding OST1, TCH2, CPK16 and CIPK9 specifically being up-regulated following combined stress. Genes encoding the MAP kinases MKK9 and MPK20 are also uniquely expressed. Ontological analysis of the transcripts uniquely up-regulated by combined stress (Figure $6 \mathrm{~b}$ and $\mathrm{c}$ and Additional file 1: Table S10) showed an enrichment of genes involved in polyamine metabolism and in particular spermidine biosynthesis such as spermidine synthase (SPDS1) and S-adenosylmethionine decarboxylase $(S A M D C)$. The transcriptomic response of Sorghum to combined heat and drought stress therefore appears unique to that when each stress is imposed individually.

\section{Discussion}

Transcriptomic analyses of plant responses to stress are an effective way in which genes, pathways and processes responsible for plant stress tolerance can be identified. Here, we examined the effect of combined heat and drought stress on the Sorghum transcriptome, using custom designed microarrays containing 28585 individual gene probes. These probes correspond to the 


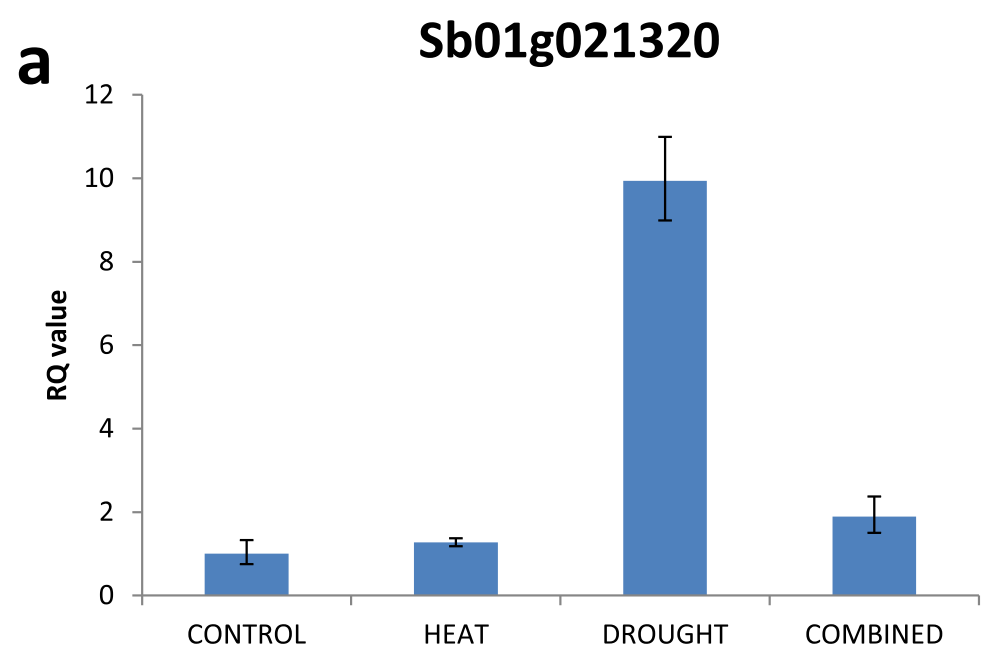

b

Sb02g038425

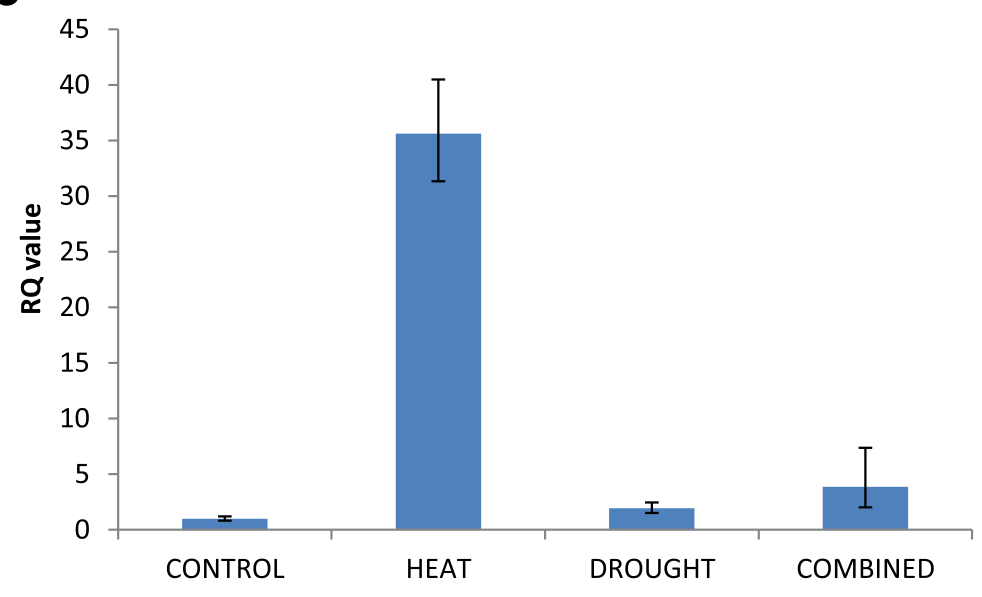

C

Sb05g017950

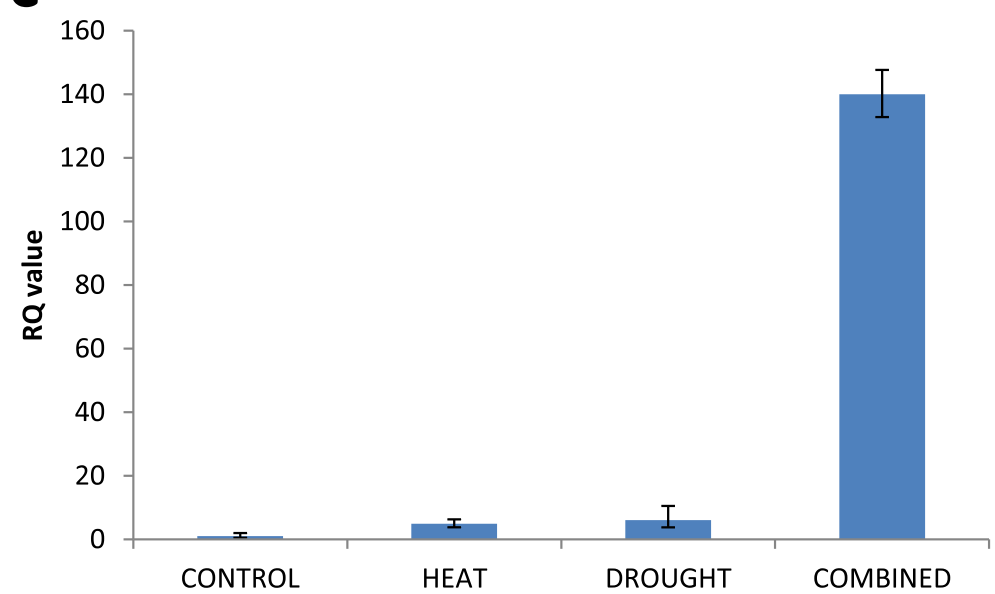

Figure 4 (See legend on next page.) 
(See figure on previous page.)

Figure 4 Relative transcript abundance of genes representative of the gene sets identified as being up-regulated preferentially by either drought stress (a), heat stress (b) or combined heat and drought stress (c). Error bars represent $R Q_{M I N}$ and $R Q_{M A X}$ and constitute the acceptable error level for a 95\% confidence level according to Student's t-test.

latest genome annotation at the time of printing therefore this is the largest microarray study carried out on Sorghum to date.

In response to drought stress we found that expression of $\sim 3.5 \%$ of the Sorghum genome was changed by $>2$-fold. The genes identified were mostly in known droughttolerance pathways and there was enrichment of expected promoter motifs. The ABA-responsive element (ABRE) for example, is a known promoter in genes induced by dehydration, salinity and ABA [28]. The number of gene changes identified here is similar to previous studies in which expression of $\sim 4 \%$ of the Sorghum genome was changed when subjected to osmotic stress by PEG treatment $[21,22]$. Out of our total 1190 drought-induced gene changes $32 \%$ were shared with the PEG induced gene changes identified by Dugas et al. using a next generation sequencing transcriptomic approach. There is a significant overlap between the studies although it is clear that the slightly different treatments i.e. a sharp osmotic shock compared to the gradual loss of water have also resulted in the induction of some different response pathways and genes. For example, there is an enrichment of genes associated with response to reactive oxygen species in the transcripts only changed by the PEG treatment whereas there is an enrichment of genes associated with wax biosynthesis in the transcripts only changed by the water withdrawal treatment imposed here. Large quantities of

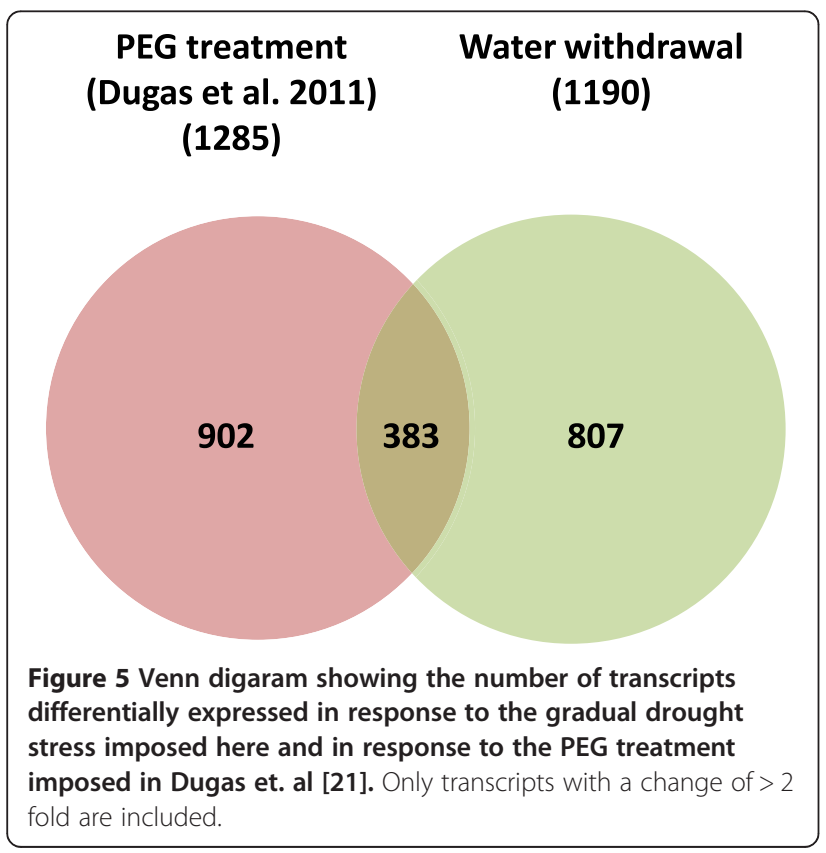

reactive oxygen species (ROI) are generated as an early response to stress [29] therefore reducing ROI levels could be seen as a short term solution to drought. The induction of wax biosynthesis genes on the other hand could result in increased epiculticuar wax which would result in reduced water loss and therefore could be seen as a longer term strategy for survival.

Heat shock resulted in $>2$-fold changes in expression of $15 \%$ of the Sorghum genome. This relatively high level of gene expression changes is not surprising given the acute, severe nature of the heat shock and is comparable to studies in other species $[12,13]$. The differentially expressed genes were mostly associated with the heat shock response and again resulted in the expected promoter motifs including CAMTA-like and heat shock elements (HSE) [30].

The combined stress response resulted in 5779 gene changes of which a large proportion were in common with the heat-regulated gene set (60\%) and around 13\% were shared with the response to drought (Figure 1). Such overlap is understandable: whilst there will be unique challenges presented to the plant when stresses are combined, there is still the need to attend to fundamental issues arising from each stress individually. Reactive oxygen intermediate (ROI) detoxification is required following a number of different stress types [31]. This is displayed here by the enrichment of the GO category 'response to reactive oxygen species' in all of the stress types studied (Additional file 1: Tables S2, S5 and S8). Many of the other GO categories enriched by combined stress share elements of those enriched following the other stress types. For example, protein folding is enriched in both the heat and combined stress response and regulation of photosynthesis and water channel activity is also enriched in the drought stress response (Figure 2). It is understandable that similar stresses would require similar downstream processes. This induction of similar pathways can produce cross-tolerance whereby previous exposure to one stress type can provide protection from another [32]. The fact that more genes were found to be in common with the heat stress response is likely to be due the acute nature of the heat shock treatment which results in more synchronised induction of genes.

Despite this large overlap however, there is obvious specificity of gene expression in that there are clear sets of genes which are only changed by the combined heat and drought treatment. These specific changes suggest that, similar to what has been found for Arabidopsis and tobacco, Sorghum has a unique transcriptional response 
Table 2 Gene Ontology (GO terms) enriched $(p<0.1)$ in both the differentially expressed genes following the drought treatment imposed here and also in the PEG treatment imposed in the Dugas et al. [21]

\begin{tabular}{|c|c|c|c|c|}
\hline GO ACCESSION & GO term & P-value & $\%$ count in selection & $\%$ count in total genome \\
\hline GO:0009644 & Response to high light intensity & 0.000 & 6.23 & 0.49 \\
\hline GO:0009415 & Response to water & 0.000 & 9.51 & 1.62 \\
\hline GO:0009266 & Response to temperature stimulus & 0.000 & 13.77 & 3.57 \\
\hline GO:0009628 & Response to abiotic stimulus & 0.000 & 23.93 & 9.56 \\
\hline GO:0010205 & Photoinhibition & 0.000 & 2.62 & 0.07 \\
\hline GO:0006950 & Response to stress & 0.000 & 28.85 & 14.70 \\
\hline GO:0006970 & Response to osmotic stress & 0.000 & 9.84 & 2.58 \\
\hline GO:0009409 & Response to cold & 0.000 & 9.51 & 2.45 \\
\hline GO:0042548 & Regulation of photosynthesis, light reaction & 0.000 & 2.62 & 0.12 \\
\hline GO:0042221 & Response to chemical stimulus & 0.000 & 25.57 & 13.05 \\
\hline GO:0009408 & Response to heat & 0.000 & 6.56 & 1.29 \\
\hline GO:0009737 & Response to abscisic acid stimulus & 0.000 & 8.85 & 2.38 \\
\hline GO:0043467 & Regulation of generation of precursor metabolites and energy & 0.000 & 2.62 & 0.21 \\
\hline GO:0042538 & Hyperosmotic salinity response & 0.002 & 3.28 & 0.49 \\
\hline GO:0050896 & Response to stimulus & 0.002 & 40.33 & 28.12 \\
\hline GO:0008287 & Protein serine/threonine phosphatase complex & 0.004 & 2.95 & 0.43 \\
\hline GO:0000302 & Response to reactive oxygen species & 0.008 & 3.93 & 0.86 \\
\hline GO:0009314 & Response to radiation & 0.010 & 9.18 & 3.82 \\
\hline GO:0006470 & Protein dephosphorylation & 0.018 & 2.95 & 0.53 \\
\hline GO:0010119 & Regulation of stomatal movement & 0.019 & 2.95 & 0.54 \\
\hline GO:0023057 & Negative regulation of signaling & 0.021 & 2.95 & 0.55 \\
\hline GO:0004722 & Protein serine/threonine phosphatase activity & 0.065 & 3.28 & 0.79 \\
\hline GO:0009719 & Response to endogenous stimulus & 0.065 & 12.79 & 6.94 \\
\hline GO:0008289 & Lipid binding & 0.066 & 3.93 & 1.12 \\
\hline
\end{tabular}

to the combined heat and drought stress [16,17]. Sorghum must therefore be able to perceive this combined stress as a unique environmental condition and reacts to it accordingly. Drought is likely perceived by proteins at the plasma membrane. For example, HK1, a transmembrane histidine kinase is thought to be the first component in relaying an osmotic stress signal to the nucleus [33]. Heat stress is sensed by a complex network of sensors which include plasma membrane proteins and components of the unfolded protein response [34]. The sensing of combined heat and drought would require crosstalk between these sensor systems, or more unlikely, a totally separate sensor for this purpose.

Specificity may also arise at the level of signal transduction. For example, mitogen-activated protein kinase (MAPK) cascades are important signal transducers. These are known to be activated by a number of abiotic stresses and can introduce specificity into a system [35]. Interestingly, there are a number of genes encoding MAP kinases, such as MPK20, which are only elevated by combined stress. Additionally, a number of genes encoding calciuminteracting proteins are specifically elevated such as
CPK16. Calcium is an important second messenger and it is thought that unique calcium signatures can result in the expression of unique sets of genes [36]. Calcium binding proteins control these responses and different isoforms have been found to be induced by different plant stresses $[10,37]$. It is therefore possible that the CDPK isoforms elevated here are involved specifically in transducing the combined stress signal.

Once in the nucleus unique transcription factors may be responsible for switching on particular sets of genes. A number of transcription factors are only elevated by combined heat and drought (Figure 2). An example transcription factor is ATAF1 which belongs to the NAC family of transcription factors. This has been found to be induced by a number of stresses in Arabidopsis including drought, salinity and wounding [38] therefore it is possible that this has evolved an alternative role in the combined stress response in Sorghum. The HSFC1 transcription factor which is known to induce HSPs in Arabidopsis is also elevated along with some unique HSPs. Other uniquely elevated chaperones include some LEAs which are hydrophilic proteins involved in stress 
Table 3 Gene Ontology (GO terms) enriched $(p<0.1)$ in the differentially expressed genes following the Sorghum PEG treatment carried out in Dugas et al. [21] but not in the drought treatment imposed here

\begin{tabular}{|c|c|c|c|c|}
\hline GO ACCESSION & GO term & P-value & $\%$ count in selection & $\%$ count in total genome \\
\hline GO:0050896 & Response to stimulus & 0.000 & 39.6 & 28.1 \\
\hline GO:0006950 & Response to stress & 0.000 & 23.7 & 14.7 \\
\hline GO:0009642 & Response to light intensity & 0.000 & 3.0 & 0.7 \\
\hline GO:0010035 & Response to inorganic substance & 0.000 & 5.5 & 2.2 \\
\hline GO:0042221 & Response to chemical stimulus & 0.000 & 19.9 & 13.1 \\
\hline GO:0006805 & Xenobiotic metabolic process & 0.001 & 1.2 & 0.1 \\
\hline GO:0009408 & Response to heat & 0.001 & 3.9 & 1.3 \\
\hline GO:0009410 & Response to xenobiotic stimulus & 0.002 & 1.2 & 0.1 \\
\hline GO:0009607 & Response to biotic stimulus & 0.002 & 10.0 & 5.5 \\
\hline GO:0051707 & Response to other organism & 0.004 & 9.3 & 5.1 \\
\hline GO:0009644 & Response to high light intensity & 0.005 & 2.1 & 0.5 \\
\hline GO:0000302 & Response to reactive oxygen species & 0.008 & 2.8 & 0.9 \\
\hline GO:0005576 & Extracellular region & 0.008 & 6.4 & 3.1 \\
\hline GO:0006026 & Aminoglycan catabolic process & 0.023 & 1.1 & 0.2 \\
\hline GO:0009055 & Electron carrier activity & 0.023 & 7.6 & 4.2 \\
\hline GO:0051704 & Multi-organism process & 0.027 & 10.7 & 6.6 \\
\hline GO:0005385 & Zinc ion transmembrane transporter activity & 0.029 & 0.8 & 0.1 \\
\hline GO:0009628 & Response to abiotic stimulus & 0.029 & 14.2 & 9.6 \\
\hline GO:0071577 & Zinc ion transmembrane transport & 0.029 & 0.8 & 0.1 \\
\hline GO:0006030 & Chitin metabolic process & 0.032 & 1.1 & 0.2 \\
\hline GO:0009719 & Response to endogenous stimulus & 0.041 & 10.9 & 6.9 \\
\hline GO:0061134 & Peptidase regulator activity & 0.083 & 1.7 & 0.4 \\
\hline
\end{tabular}

protection. It is possible that these known chaperone molecules contain different motifs which allow recognition and binding of a specific set of molecular targets (OlveraCarrillo, 2011) and has similarly been shown to be the case in the combined stress response of Arabidopsis [17]. It must be borne in mind however, that these experiments were carried out at one specific time point therefore a detailed time course is required to be able to draw more detailed conclusions.

Amongst other downstream genes regulated by combined stress were those encoding enzymes which are involved in the biosynthesis of polyamines and in particular spermidine such as SAMDC and SPDS1. Polyamines have been implicated in tolerance to multiple stresses including high and low temperature, oxidative stress and salinity $[39,40]$. They have been suggested to play a role in ROI scavenging and membrane protection [41]. Perhaps the combined heat and drought treatment results in a higher levels of ROI production than heat and drought treatment individually and therefore higher polyamine levels are required to counteract this. Interestingly, one of the uniquely elevated transcription factors, WOX1,

Table 4 Gene Ontology (GO terms) enriched $(p<0.1)$ in the differentially expressed genes following the drought treatment imposed here but not in the PEG treatment imposed in the Dugas et al. [21]

\begin{tabular}{|c|c|c|c|c|}
\hline GO ACCESSION & GO term & P-value & $\%$ count in selection & $\%$ count in total genome \\
\hline GO:0010025 & Wax biosynthetic process & 0.065 & 1.50 & 0.25 \\
\hline GO:0032787 & Monocarboxylic acid metabolic process & 0.065 & 5.26 & 2.35 \\
\hline GO:0042221 & Response to chemical stimulus & 0.068 & 18.80 & 13.05 \\
\hline GO:0016740 & Rransferase activity & 0.081 & 25.26 & 18.90 \\
\hline GO:0043765 & T/G mismatch-specific endonuclease activity & 0.081 & 0.60 & 0.03 \\
\hline GO:0003824 & Catalytic activity & 0.084 & 58.95 & 51.25 \\
\hline GO:0050896 & Response to stimulus & 0.084 & 35.19 & 28.12 \\
\hline
\end{tabular}


Table 5 Top 100 genes differentially expressed in response to heat (based on average absolute fold change) compared to control unstressed plants

\begin{tabular}{|c|c|c|c|}
\hline SbID & Annotation & $\begin{array}{l}\text { Average fold } \\
\text { change (Abs) }\end{array}$ & Regulation \\
\hline Sb06g017850.1 & HSP22.0 & 5670.2 & Up \\
\hline Sb03g034390.1 & HSP101 & 4552.7 & Up \\
\hline Sb10g012970.1 & $\begin{array}{l}\text { Peptidyl-prolyl cis-trans } \\
\text { isomerase, putative }\end{array}$ & 1854.5 & Up \\
\hline Sb01g039990.1 & HSP18.2 & 1738.0 & Up \\
\hline Sb01g040000.1 & HSP18.2 & 1567.4 & Up \\
\hline Sb04g034630.1 & $\begin{array}{l}\text { Universal stress protein } \\
\text { (USP) family protein }\end{array}$ & 1510.5 & Up \\
\hline Sb06g016710.1 & RAP2.6 (related to AP2 6) & 1459.0 & Up \\
\hline Sb09g022400.1 & Cytochrome-c oxidase & 1437.9 & Up \\
\hline Sb06g000660.1 & HSP90.1 & 1425.2 & Up \\
\hline Sb03g003530.1 & $\begin{array}{l}\text { HSP 17.6川 (17.6 KDA CLASS ॥ } \\
\text { HEAT SHOCK PROTEIN) }\end{array}$ & 1021.6 & Up \\
\hline Sb01g015760.1 & $\begin{array}{l}\text { Scarecrow-like transcription } \\
\text { factor } 9 \text { (SCL9) }\end{array}$ & 1018.0 & Up \\
\hline Sb02g042790.1 & Unknown protein & 1000.0 & Up \\
\hline Sb03g006920.1 & $\begin{array}{l}\text { HSP18.2 (heat shock } \\
\text { protein 18.2) }\end{array}$ & 984.6 & Up \\
\hline Sb04g007585.1 & $\begin{array}{l}\text { HSP17.6A (HEAT SHOCK } \\
\text { PROTEIN 17.6A) }\end{array}$ & 832.2 & Up \\
\hline Sb04g007600.1 & $\begin{array}{l}\text { HSP17.6A (HEAT SHOCK } \\
\text { PROTEIN 17.6A) }\end{array}$ & 820.9 & Up \\
\hline Sb04g030895.1 & Unknown protein & 785.0 & Up \\
\hline Sb04g030895.2 & Unknown protein & 710.6 & Up \\
\hline Sb10g008130.1 & FTSH6 (FTSH PROTEASE 6) & 676.4 & Up \\
\hline Sb05g021400.1 & CYP76C2 & 512.6 & Up \\
\hline Sb02g026070.1 & Unknown protein & 491.0 & Up \\
\hline Sb03g006900.1 & $\begin{array}{l}\text { HSP18.2 (heat shock } \\
\text { protein 18.2) }\end{array}$ & 451.6 & Up \\
\hline Sb07g028370.1 & $\begin{array}{l}\text { HSP21 (HEAT SHOCK } \\
\text { PROTEIN 21) }\end{array}$ & 451.2 & Up \\
\hline Sb06g030310.1 & $\begin{array}{l}\text { Pectinesterase family } \\
\text { protein }\end{array}$ & 446.2 & Up \\
\hline Sb08g002950.1 & Unknown protein & 412.0 & Up \\
\hline Sb01g010460.1 & BIP1 & 364.4 & Up \\
\hline Sb10g007320.1 & OPR2 & 324.5 & Up \\
\hline Sb09g027030.1 & $\begin{array}{l}\text { Basic helix-loop-helix } \\
\text { (bHLH) family protein }\end{array}$ & 318.1 & Up \\
\hline Sb03g006880.1 & $\begin{array}{l}\text { HSP18.2 (heat shock } \\
\text { protein 18.2) }\end{array}$ & 313.4 & Up \\
\hline Sb08g020850.1 & $\begin{array}{l}\text { Lectin protein kinase, } \\
\text { putative }\end{array}$ & 303.8 & Up \\
\hline Sb07g001530.1 & Unknown protein & 303.7 & Up \\
\hline Sb10g025830.1 & Unknown protein & 287.7 & Up \\
\hline Sb09g024255.1 & EDL3 (EID1-like 3) & 261.0 & Up \\
\hline Sb01g015750.1 & Unknown protein & 253.7 & Up \\
\hline
\end{tabular}

Table 5 Top 100 genes differentially expressed in response to heat (based on average absolute fold change) compared to control unstressed plants (Continued)

\begin{tabular}{|c|c|c|c|}
\hline Sb04g030135.1 & $\begin{array}{l}17.6 \mathrm{kDa} \text { class I small heat } \\
\text { shock protein (HSP17.6C-Cl) }\end{array}$ & 253.0 & Up \\
\hline Sb01g046350.1 & HSFA6B & 241.9 & Up \\
\hline Sb01g038670.1 & $\begin{array}{l}\text { Low temperature and salt } \\
\text { responsive protein }\end{array}$ & 234.3 & Up \\
\hline Sb01g030345.1 & $\begin{array}{l}\text { Plant EC metallothionein-like } \\
\text { family } 15 \text { protein }\end{array}$ & 229.5 & Up \\
\hline Sb02g030040.1 & $\begin{array}{l}\text { UDP-glucoronosyl/UDP- } \\
\text { glucosyl transferase family } \\
\text { protein }\end{array}$ & 221.6 & Up \\
\hline Sb05g018030.1 & $\begin{array}{l}\text { BAG5 (BCL-2-ASSOCIATED } \\
\text { ATHANOGENE 5) }\end{array}$ & 213.5 & Up \\
\hline Sb03g006890.1 & $\begin{array}{l}\text { HSP18.2 } \\
\text { (heat shock protein 18.2) }\end{array}$ & 210.9 & Up \\
\hline Sb10g023010.1 & $\begin{array}{l}\text { MBF1C (MULTIPROTEIN } \\
\text { BRIDGING FACTOR 1C) }\end{array}$ & 205.4 & Up \\
\hline Sb05g008770.1 & $\begin{array}{l}\text { Disease resistance- } \\
\text { responsive family protein }\end{array}$ & 204.0 & Up \\
\hline Sb09g023040.1 & $\begin{array}{l}\text { Phosphatidylethanolamine- } \\
\text { binding family protein }\end{array}$ & 203.8 & Up \\
\hline Sb04g027330.1 & $\begin{array}{l}23.5 \text { kDa mitochondrial } \\
\text { small heat shock protein } \\
\text { (HSP23.5-M) }\end{array}$ & 197.4 & Up \\
\hline Sb02g026600.1 & CYP707A4 & 195.6 & Up \\
\hline Sb10g007330.1 & OPR2 & 188.9 & Up \\
\hline Sb08g001520.1 & $\begin{array}{l}\text { No apical meristem (NAM) } \\
\text { family protein }\end{array}$ & 188.3 & Up \\
\hline Sb06g001970.1 & $\begin{array}{l}\text { APX3 (ASCORBATE } \\
\text { PEROXIDASE 3) }\end{array}$ & 181.9 & Up \\
\hline Sb03g032910.1 & Unknown protein & 179.3 & Up \\
\hline Sb03g038160.1 & $\begin{array}{l}\text { C4H (CINNAMATE-4- } \\
\text { HYDROXYLASE) }\end{array}$ & 178.0 & Up \\
\hline Sb03g012940.1 & $\begin{array}{l}\text { SAG21 (SENESCENCE- } \\
\text { ASSOCIATED GENE 21) }\end{array}$ & 177.6 & Up \\
\hline Sb01g027480.1 & Unknown protein & 170.0 & Up \\
\hline Sb01g008350.1 & Glutamate binding & 163.9 & Up \\
\hline Sb02g025930.1 & $\begin{array}{l}\text { GEX1 (GAMETE EXPRESSED } \\
\text { PROTEIN 1) }\end{array}$ & 155.6 & Up \\
\hline Sb03g041980.1 & $\begin{array}{l}\text { Pentatricopeptide (PPR) } \\
\text { repeat-containing protein }\end{array}$ & 154.9 & Up \\
\hline Sb09g027890.1 & Ferredoxin-related & 148.2 & Up \\
\hline Sb10g009970.1 & $\begin{array}{l}\text { Protein kinase family } \\
\text { protein }\end{array}$ & 142.4 & Up \\
\hline Sb10g009090.1 & $\begin{array}{l}15.7 \text { kDa class I-related } \\
\text { small heat shock protein- } \\
\text { like (HSP15.7-Cl) }\end{array}$ & 140.2 & Up \\
\hline Sb05g027880.1 & RCA (RUBISCO ACTIVASE) & 137.7 & Up \\
\hline Sb06g016240.1 & Nucleic acid binding & 134.1 & Up \\
\hline Sb02g025930.2 & Unknown protein & 129.4 & Up \\
\hline Sb01g040025.1 & EDM2; transcription factor & 129.4 & Up \\
\hline
\end{tabular}


Table 5 Top 100 genes differentially expressed in response to heat (based on average absolute fold change) compared to control unstressed plants (Continued)

\begin{tabular}{|c|c|c|c|}
\hline Sb02g028060.1 & Unknown protein & 129.0 & Up \\
\hline Sb1058s002010 & Unknown protein & 119.0 & Up \\
\hline Sb03g005090.1 & $\begin{array}{l}\text { tRLP7 (Receptor Like } \\
\text { Protein 7) }\end{array}$ & 117.8 & Up \\
\hline Sb06g001260.1 & $\begin{array}{l}\text { ACX4 } \\
\text { (ACYL-COA OXIDASE 4) }\end{array}$ & 115.5 & Up \\
\hline Sb01g039436.1 & $\begin{array}{l}\text { Heat shock cognate } 70 \mathrm{kDa} \\
\text { protein } 2 \text { (HSC70-2) }\end{array}$ & 113.4 & Up \\
\hline Sb09g024180.1 & $\begin{array}{l}\text { CYC1BAT; cyclin-dependent } \\
\text { protein kinase regulator }\end{array}$ & 111.1 & Up \\
\hline Sb07g003040.1 & $\begin{array}{l}\text { Tyrosine decarboxylase, } \\
\text { putative }\end{array}$ & 106.9 & Up \\
\hline Sb07g019840.1 & CFIM-25 & 103.9 & Up \\
\hline Sb01g037590.1 & Unknown protein & 103.3 & Up \\
\hline Sb01g016900.1 & CYP76C1 & 102.6 & Up \\
\hline Sb07g025210.1 & $\begin{array}{l}\text { DREB1A (DEHYDRATION } \\
\text { RESPONSE ELEMENT B1A) }\end{array}$ & 102.0 & Up \\
\hline Sb02g017220.2 & unknown protein & 100.3 & Up \\
\hline Sb08g000570.1 & unknown protein & 98.8 & Up \\
\hline Sb10g003880.1 & $\begin{array}{l}\text { carboxylesterase/ } \\
\text { hydrolase/ hydrolase, } \\
\text { acting on ester bonds }\end{array}$ & 98.5 & Up \\
\hline Sb04g024540.1 & unknown protein & 97.7 & Up \\
\hline Sb10g007430.1 & glycine-rich protein & 97.6 & Up \\
\hline Sb02g017220.1 & Metal ion binding & 97.4 & Up \\
\hline Sb03g034980.1 & $\begin{array}{l}\text { KAT1 (POTASSIUM } \\
\text { CHANNEL IN ARABIDOPSIS } \\
\text { THALIANA 1) }\end{array}$ & 90.6 & Up \\
\hline Sb01g009370.1 & $\begin{array}{l}\text { EGY3 (ETHYLENE- } \\
\text { DEPENDENT GRAVITROPISM- } \\
\text { DEFICIENT AND YELLOW- } \\
\text { GREEN-LIKE 3) }\end{array}$ & 90.5 & Up \\
\hline Sb01g039510.1 & $\begin{array}{l}\text { HSC70-1 (HEAT SHOCK } \\
\text { COGNATE PROTEIN 70-1) }\end{array}$ & 90.2 & Up \\
\hline Sb01g037090.1 & $\begin{array}{l}\text { GolS1 (Arabidopsis thaliana } \\
\text { galactinol synthase 1) }\end{array}$ & 89.6 & Up \\
\hline Sb01g014230.1 & $\begin{array}{l}\text { 5PTASE11 (INOSITOL } \\
\text { POLYPHOSPHATE 5- } \\
\text { PHOSPHATASE 11) }\end{array}$ & 87.2 & Up \\
\hline Sb01g041180.1 & $\begin{array}{l}\text { HSP21 (HEAT SHOCK } \\
\text { PROTEIN 21) }\end{array}$ & 87.1 & Up \\
\hline Sb04g035130.1 & $\begin{array}{l}17.4 \mathrm{kDa} \text { class III heat shock } \\
\text { protein (HSP17.4-CIII) }\end{array}$ & 84.7 & Up \\
\hline Sb01g040030.1 & HSP17.4 & 84.5 & Up \\
\hline Sb02g009720.1 & Unknown protein & 82.8 & Up \\
\hline Sb08g001710.1 & MATE efflux family protein & 81.6 & Up \\
\hline Sb02g009430.1 & $\begin{array}{l}\text { UBX domain-containing } \\
\text { protein }\end{array}$ & 81.2 & Up \\
\hline Sb01g047480.1 & $\begin{array}{l}\text { Zinc finger (C3HC4-type } \\
\text { RING finger) family protein }\end{array}$ & 79.5 & Up \\
\hline
\end{tabular}

Table 5 Top 100 genes differentially expressed in response to heat (based on average absolute fold change) compared to control unstressed plants (Continued)

\begin{tabular}{|c|c|c|c|}
\hline Sb01g039470.1 & $\begin{array}{l}\text { HSP70 } \\
\text { (heat shock protein 70) }\end{array}$ & 77.7 & Up \\
\hline Sb06g027420.1 & AOX1B; alternative oxidase & 75.1 & Up \\
\hline Sb06g026350.1 & $\begin{array}{l}\text { Oxidoreductase, } 2 \mathrm{OG}-\mathrm{Fe}(\mathrm{II}) \\
\text { oxygenase family protein }\end{array}$ & 73.8 & Up \\
\hline Sb10g009140.1 & $\begin{array}{l}\text { Caleosin-related family } \\
\text { protein }\end{array}$ & 73.5 & Up \\
\hline Sb01g003280.1 & $\begin{array}{l}\text { Zinc finger ( }(\mathrm{C} 2 \mathrm{H} 2 \text { type) } \\
\text { family protein }\end{array}$ & 72.7 & Up \\
\hline Sb06g023160.1 & $\begin{array}{l}\text { Trypsin and protease } \\
\text { inhibitor family protein }\end{array}$ & 72.6 & Up \\
\hline Sb01g004060.1 & CYP76C2 & 72.0 & Up \\
\hline Sb07g016730.1 & Unknown protein & 70.1 & Up \\
\hline Sb09g030140.1 & $\begin{array}{l}\text { Glycoside hydrolase family } \\
28 \text { protein }\end{array}$ & 69.4 & Up \\
\hline
\end{tabular}

has been shown to physically interact with SAMDC suggesting a possible way in which the activity of this enzyme is regulated by combined stress [42].

\section{Conclusions}

It is clear that there is a degree of plasticity in the Sorghum response to abiotic stress, with evidence for both crosstalk and specificity. This is similar to previous findings in Arabidopsis and tobacco suggesting conservation of mechanisms across species. There are however some elements of the combined stress response which appear unique to Sorghum such as a potential role for polyamine biosynthesis and specific transcription factors and signalling molecules. A functional characterization of these identified genes and pathways is required as they could be used as possible targets for the enhancement of stress tolerance either by marker assisted selection or transgenics. Given the predicted increase in prevalence of drought and heat stress on agricultural land there is a further need to analyse the effect of combined stress on crop species.

\section{Methods}

Plant growth conditions and stress treatments

Seeds of Sorghum (Sorghum bicolor L. Moench.) R16 variety were imbibed overnight in water and surface-sown singly onto soaked $42 \mathrm{~mm}$ Jiffy peat pellets (LBS horticulture Ltd, Lancashire, UK). Seedlings were grown in a controlled growth chamber at $28^{\circ} \mathrm{C}$ day, $23^{\circ} \mathrm{C}$ night, $12 \mathrm{~h}$ photoperiod and set to $0 \%$ humidity. Plants were subjected either to control (no treatment), heat, drought or combined heat and drought conditions (6 plants per treatment). These stress assays were developed specifically for Sorghum and are detailed below. Drought stress 
Table 6 Top 100 genes differentially expressed in response to combined heat and drought stress (based on average absolute fold change) compared to control unstressed plants

\begin{tabular}{|c|c|c|c|}
\hline SbID & Annotation & $\begin{array}{l}\text { Average fold } \\
\text { change (Abs) }\end{array}$ & Regulation \\
\hline Sb06g017850.1 & HSP22.0 & 17429.6 & Up \\
\hline Sb03g034390.1 & $\begin{array}{l}\text { HSP101 (HEAT SHOCK } \\
\text { PROTEIN 101) }\end{array}$ & 16893.6 & Up \\
\hline Sb10g012970.1 & $\begin{array}{l}\text { Peptidyl-prolyl cis-trans } \\
\text { isomerase }\end{array}$ & 6262.9 & Up \\
\hline Sb04g034630.1 & $\begin{array}{l}\text { Universal stress protein } \\
\text { (USP) family protein }\end{array}$ & 5788.6 & Up \\
\hline Sb04g030135.1 & $\begin{array}{l}17.6 \mathrm{kDa} \text { class I small heat } \\
\text { shock protein (HSP17.6C-CI) }\end{array}$ & 5135.6 & Up \\
\hline Sb06g000660.1 & $\begin{array}{l}\text { HSP90.1 (HEAT SHOCK } \\
\text { PROTEIN 90.1) }\end{array}$ & 4744.9 & Up \\
\hline Sb02g042790.1 & Unknown protein & 4705.1 & Up \\
\hline Sb09g022400.1 & Cytochrome-c oxidase & 4527.3 & Up \\
\hline Sb01g015760.1 & $\begin{array}{l}\text { Scarecrow-like transcription } \\
\text { factor } 9 \text { (SCL9) }\end{array}$ & 3631.6 & Up \\
\hline Sb03g003530.1 & $\begin{array}{l}\text { HSP17.6川 (17.6 KDA CLASS ॥ } \\
\text { HEAT SHOCK PROTEIN) }\end{array}$ & 3174.2 & Up \\
\hline Sb03g006920.1 & $\begin{array}{l}\text { HSP18.2 (heat shock } \\
\text { protein 18.2) }\end{array}$ & 3167.3 & Up \\
\hline Sb01g039990.1 & $\begin{array}{l}\text { HSP18.2 (heat shock } \\
\text { protein 18.2) }\end{array}$ & 2929.5 & Up \\
\hline Sb01g010460.1 & $\mathrm{BIP1}$ & 2856.4 & Up \\
\hline Sb05g021400.1 & CYP76C2 & 2799.2 & Up \\
\hline Sb01g040000.1 & $\begin{array}{l}\text { HSP18.2 (heat shock } \\
\text { protein 18.2) }\end{array}$ & 2561.3 & Up \\
\hline Sb06g030310.1 & $\begin{array}{l}\text { pectinesterase family } \\
\text { protein }\end{array}$ & 2467.5 & Up \\
\hline Sb04g007585.1 & $\begin{array}{l}\text { HSP17.6A (HEAT SHOCK } \\
\text { PROTEIN 17.6A) }\end{array}$ & 2375.8 & Up \\
\hline Sb04g007600.1 & $\begin{array}{l}\text { HSP17.6A (HEAT SHOCK } \\
\text { PROTEIN 17.6A) }\end{array}$ & 2356.4 & Up \\
\hline Sb01g046000.1 & Unknown protein & 2277.8 & Up \\
\hline Sb10g008130.1 & FTSH6 (FTSH PROTEASE 6) & 2085.7 & Up \\
\hline Sb06g016710.1 & RAP2.6 (related to AP2 6) & 1584.4 & Up \\
\hline Sb07g028370.1 & $\begin{array}{l}\text { HSP21 (HEAT SHOCK } \\
\text { PROTEIN 21) }\end{array}$ & 1286.9 & Up \\
\hline Sb08g002950.1 & Unknown protein & 1276.5 & Up \\
\hline Sb03g006900.1 & $\begin{array}{l}\text { HSP18.2 (heat shock } \\
\text { protein 18.2) }\end{array}$ & 1240.0 & Up \\
\hline Sb07g026340.1 & F-box family protein & 1180.5 & Up \\
\hline Sb05g018030.1 & $\begin{array}{l}\text { BAG5 (BCL-2-ASSOCIATED } \\
\text { ATHANOGENE 5) }\end{array}$ & 1162.8 & Up \\
\hline Sb02g028060.1 & Unknown protein & 1142.1 & Up \\
\hline Sb08g020850.1 & $\begin{array}{l}\text { Lectin protein kinase, } \\
\text { putative }\end{array}$ & 1128.9 & Up \\
\hline Sb07g021850.1 & Unknown protein & 1097.8 & Up \\
\hline Sb09g024255.1 & EDL3 (EID1-like 3) & 994.9 & Up \\
\hline
\end{tabular}

Table 6 Top 100 genes differentially expressed in response to combined heat and drought stress (based on average absolute fold change) compared to control unstressed plants (Continued)

\begin{tabular}{|c|c|c|c|}
\hline Sb01g038670.1 & $\begin{array}{l}\text { Hydrophobic protein, } \\
\text { putative }\end{array}$ & 981.7 & Up \\
\hline Sb10g028640.2 & Unknown protein & 976.7 & Up \\
\hline Sb08g000570.1 & Unknown protein & 924.9 & Up \\
\hline Sb09g027110.2 & Unknown protein & 815.4 & Up \\
\hline Sb09g027110.1 & LEA protein & 806.6 & Up \\
\hline Sb09g027890.1 & Ferredoxin-related & 769.4 & Up \\
\hline Sb03g029830.1 & Unknown protein & 744.5 & Up \\
\hline Sb10g023010.1 & $\begin{array}{l}\text { MBF1C (MULTIPROTEIN } \\
\text { BRIDGING FACTOR 1C) }\end{array}$ & 700.8 & Up \\
\hline Sb04g032890.1 & Unknown protein & 694.9 & Up \\
\hline Sb07g001530.1 & Unknown protein & 664.5 & Up \\
\hline Sb01g015750.1 & Unknown protein & 661.5 & Up \\
\hline Sb04g030895.1 & Unknown protein & 636.7 & Up \\
\hline Sb08g023230.1 & Unknown protein & 625.0 & Up \\
\hline Sb05g008770.1 & $\begin{array}{l}\text { Disease resistance- } \\
\text { responsive family protein }\end{array}$ & 608.9 & Up \\
\hline Sb04g030895.2 & Unknown protein & 602.7 & Up \\
\hline Sb03g034280.1 & $\begin{array}{l}\text { NADP-ME1 (NADP-malic } \\
\text { enzyme 1) }\end{array}$ & 582.7 & Up \\
\hline Sb09g023040.1 & $\begin{array}{l}\text { Phosphatidylethanolamine- } \\
\text { binding family protein }\end{array}$ & 569.4 & Up \\
\hline Sb03g006880.1 & $\begin{array}{l}\text { HSP18.2 (heat shock } \\
\text { protein 18.2) }\end{array}$ & 567.1 & Up \\
\hline Sb01g030345.1 & $\begin{array}{l}\text { Plant EC metallothionein- } \\
\text { like family } 15 \text { protein }\end{array}$ & 536.6 & Up \\
\hline Sb04g035130.1 & $\begin{array}{l}17.4 \text { kDa class III heat shock } \\
\text { protein (HSP17.4-CIII) }\end{array}$ & 515.5 & Up \\
\hline Sb10g009970.1 & Protein kinase family protein & 506.1 & Up \\
\hline Sb01g039436.1 & $\begin{array}{l}\text { Heat shock cognate } 70 \mathrm{kDa} \\
\text { protein } 2 \text { (HSC70-2) }\end{array}$ & 489.0 & Up \\
\hline Sb07g000520.1 & CYP71A25 & 452.0 & Up \\
\hline Sb06g004280.1 & Transketolase, putative & 449.2 & Up \\
\hline Sb02g026070.1 & Unknown protein & 441.9 & Up \\
\hline Sb06g001970.1 & $\begin{array}{l}\text { APX3 (ASCORBATE } \\
\text { PEROXIDASE 3) }\end{array}$ & 433.7 & Up \\
\hline Sb09g018420.1 & $\begin{array}{l}\text { RAB18 (RESPONSIVE TO } \\
\text { ABA 18) }\end{array}$ & 428.4 & Up \\
\hline Sb04g027330.1 & $\begin{array}{l}23.5 \mathrm{kDa} \text { mitochondrial } \\
\text { small heat shock protein } \\
\text { (HSP23.5-M) }\end{array}$ & 421.7 & Up \\
\hline Sb09g027030.1 & $\begin{array}{l}\text { Basic helix-loop-helix } \\
\text { (bHLH) family protein }\end{array}$ & 417.0 & Up \\
\hline Sb03g001130.1 & $\begin{array}{l}\text { AAA-type ATPase family } \\
\text { protein }\end{array}$ & 414.0 & Up \\
\hline Sb07g003040.1 & $\begin{array}{l}\text { Tyrosine decarboxylase, } \\
\text { putative }\end{array}$ & 410.9 & Up \\
\hline & Un & & \\
\hline
\end{tabular}


Table 6 Top 100 genes differentially expressed in response to combined heat and drought stress (based on average absolute fold change) compared to control unstressed plants (Continued)

\begin{tabular}{|c|c|c|c|}
\hline Sb07g027140.1 & Unknown protein & 401.4 & Up \\
\hline Sb02g009430.1 & $\begin{array}{l}\text { UBX domain-containing } \\
\text { protein }\end{array}$ & 386.7 & Up \\
\hline Sb01g046490.1 & LEA protein & 379.2 & Up \\
\hline Sb02g031940.1 & $\begin{array}{l}\text { FMO1 (FLAVIN-DEPENDENT } \\
\text { MONOOXYGENASE 1) }\end{array}$ & 365.8 & down \\
\hline Sb08g001520.1 & $\begin{array}{l}\text { No apical meristem (NAM) } \\
\text { family protein }\end{array}$ & 343.9 & Up \\
\hline Sb03g006890.1 & $\begin{array}{l}\text { HSP18.2 (heat shock protein } \\
\text { 18.2) }\end{array}$ & 343.6 & Up \\
\hline Sb06g023160.1 & $\begin{array}{l}\text { Trypsin and protease } \\
\text { inhibitor family protein }\end{array}$ & 341.9 & Up \\
\hline Sb10g007320.1 & OPR2 & 339.7 & Up \\
\hline Sb01g040025.1 & EDM2 & 337.0 & Up \\
\hline Sb05g003200.1 & $\begin{array}{l}\text { Phosphatidylethanolamine } \\
\text { binding }\end{array}$ & 335.7 & Up \\
\hline Sb07g003010.1 & $\begin{array}{l}\text { Tyrosine decarboxylase, } \\
\text { putative }\end{array}$ & 335.6 & Up \\
\hline Sb01g008350.1 & Glutamate binding & 332.5 & Up \\
\hline Sb01g026780.1 & Unknown protein & 322.7 & Up \\
\hline Sb04g031810.1 & Unknown protein & 320.5 & Up \\
\hline Sb06g016240.1 & Nucleic acid binding & 318.6 & Up \\
\hline Sb01g046350.1 & HSFA6B & 310.5 & Up \\
\hline Sb01g009370.1 & $\begin{array}{l}\text { EGY3 (ETHYLENE- } \\
\text { DEPENDENT GRAVITROPISM- } \\
\text { DEFICIENT AND YELLOW- } \\
\text { GREEN-LIKE 3) }\end{array}$ & 296.4 & Up \\
\hline Sb03g038160.1 & $\begin{array}{l}\text { C4H (CINNAMATE-4- } \\
\text { HYDROXYLASE) }\end{array}$ & 294.8 & Up \\
\hline Sb02g034590.1 & Aconitate hydratase & 287.0 & Up \\
\hline Sb05g027880.1 & RCA (RUBISCO ACTIVASE) & 285.7 & Up \\
\hline Sb03g041980.1 & $\begin{array}{l}\text { Pentatricopeptide (PPR) } \\
\text { repeat-containing protein }\end{array}$ & 284.7 & Up \\
\hline Sb08g005220.1 & Unknown protein & 272.7 & Up \\
\hline Sb01g039470.1 & $\begin{array}{l}\text { HSP70 (heat shock protein } \\
\text { 70) }\end{array}$ & 271.7 & Up \\
\hline Sb07g014620.1 & $\begin{array}{l}\text { DNAJ heat shock protein, } \\
\text { putative }\end{array}$ & 270.1 & Up \\
\hline Sb09g028410.1 & $\begin{array}{l}\text { DNAJ heat shock family } \\
\text { protein }\end{array}$ & 268.3 & Up \\
\hline Sb03g005090.1 & $\begin{array}{l}\text { AtRLP7 (Receptor Like } \\
\text { Protein 7) }\end{array}$ & 260.8 & Up \\
\hline Sb03g012940.1 & $\begin{array}{l}\text { SAG21 (SENESCENCE- } \\
\text { ASSOCIATED GENE 21) }\end{array}$ & 259.2 & Up \\
\hline Sb02g013190.1 & Unknown protein & 255.0 & Up \\
\hline Sb07g021840.1 & Unknown protein & 250.7 & Up \\
\hline Sb02g017220.2 & Unknown protein & 247.7 & Up \\
\hline
\end{tabular}

Table 6 Top 100 genes differentially expressed in response to combined heat and drought stress (based on average absolute fold change) compared to control unstressed plants (Continued)

\begin{tabular}{llll}
\hline Sb10g009090.1 & $\begin{array}{l}15.7 \text { kDa class I-related } \\
\text { small heat shock protein- } \\
\text { like (HSP15.7-Cl) }\end{array}$ & 246.2 & Up \\
Sb02g017220.1 & Metal ion binding & 243.7 & Up \\
Sb01g034800.1 & Nucleic acid binding & 242.5 & Up \\
Sb01g042680.1 & $\begin{array}{l}\text { HSP70T-2 (HEAT-SHOCK } \\
\text { PROTEIN 70 T-2) }\end{array}$ & 235.4 & Up \\
Sb02g030040.1 & $\begin{array}{l}\text { UDP-glucosyl transferase } \\
\text { family protein }\end{array}$ & 230.6 & Up \\
Sb10g000930.1 & $\begin{array}{l}\text { LEA group 1 domain- } \\
\text { COntaining protein }\end{array}$ & 230.2 & Up \\
Sb10g003700.1 & XERO1 (DEHYDRIN XERO 1) 230.2 & Up \\
Sb01g000352.1 & $\begin{array}{l}\text { ERF1 (ETHYLENE RESPONSE } 224.2 \\
\text { FACTOR 1) }\end{array}$ & Up \\
& & &
\end{tabular}

was applied to the "drought" and "heat and drought" plants by withholding water from 14 days after sowing. At this stage the seedlings had 3 leaves. The remaining plants were well watered. The first visual symptoms of drought stress appeared in the form of leaf curling and slight wilting at 4 days following water withdrawal. This is similar to previous studies in which plants grown under similar conditions showed signs of water stress including a reduction in $\mathrm{CO}_{2}$ assimilation and reduced transpiration rate after 4 days of withholding water [43]. Measurements of the ratio of variable fluorescence $\left(\mathrm{F}_{\mathrm{v}}\right)$ to maximal fluorescence $\left(\mathrm{F}_{\mathrm{m}}\right)$ of plant photosystems can be used as a proxy for the stress status of plants because a reduction in $\mathrm{Fv} / \mathrm{Fm}$ indicates photoinibition and therefore that a plant is actually experiencing stress $[23,24]$. Therefore in order to quantify when drought stress was first starting to have a physiological effect, the $\mathrm{F}_{\mathrm{v}} / \mathrm{F}_{\mathrm{m}}$ of all of the plants was measured daily using a FluorCam 700mf (Photon Systems instruments, Brno, Czech Republic) on the $F_{o}, F_{m}$ and Kautsky effect setting. All plants were dark acclimated for 30 mins prior to measurements. At the timepoint at which the $\mathrm{F}_{\mathrm{v}} / \mathrm{F}_{\mathrm{m}}$ of the un-watered plants was first significantly lower (error bars showing standard error are no longer overlapping) than that of the watered plants, they were subject to either heat shock by incubation in the dark (to ensure equal levels of light) at $50^{\circ} \mathrm{C}$ for $3 \mathrm{~h}$ (heat and combined treatment) or $28^{\circ} \mathrm{C}$ for $3 \mathrm{~h}$ (control and drought treatment). The youngest 3 leaves were sampled and tissue was pooled for each treatment set. Experiments were carried out in triplicate to give 3 biological replicates. All treatments were carried out at the same time of day for each biological replicate to reduce variation due to circadian/diurnal factors. Tissues 

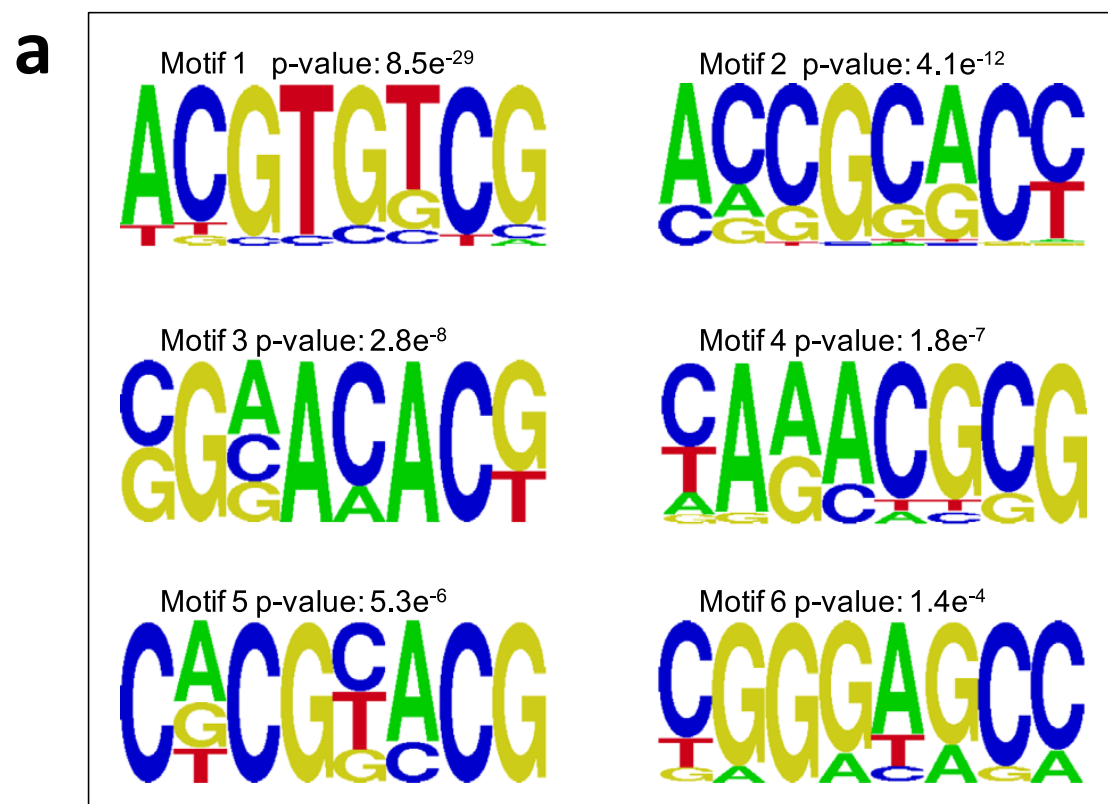
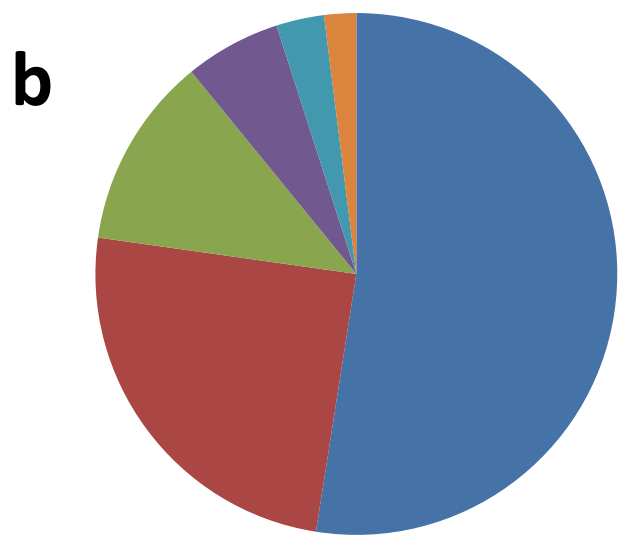

C

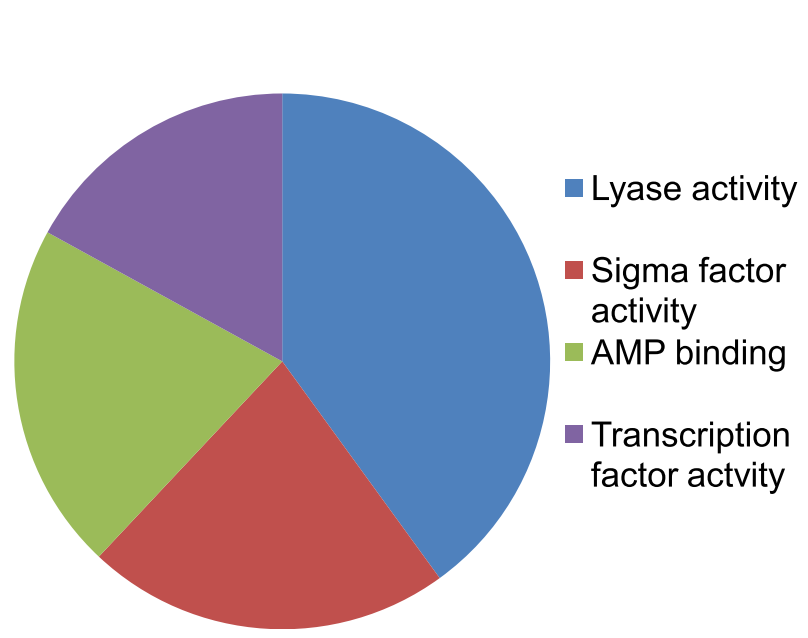
reproduction

- Protein ubiquitination

- Respons to stimulus

- Potassium ion transport

C
Response to stress

Amine metabolism

- Process involved in

Figure 6 (See legend on next page.) 
(See figure on previous page.)

Figure 6 Analysis of genes up-regulated only by combined heat and drought treatment. (a) Most significantly enriched sequences found in promoters of genes uniquely upregulated in response to combined heat and drought. Figure shows top 6 statistically significant consensus sequences generating using AMADEUS and enoLOGOS. Probability values representing significance of enrichment (calculated as described in Methods) are shown for each motif. (b \& c) Ontological analysis showing enriched biological process (b) and molecular function (c) GO terms $p<0.05$. Ontological terms were summarized using the REVIGO tool. Detailed breakdowns of the ontologies are available in Additional file 1 : Table 510.

samples were harvested into liquid nitrogen and stored at $-80^{\circ} \mathrm{C}$.

\section{Microarray design}

Custom expression microarrays (4X44K format) for Sorghum were designed and submitted for manufacturing using the Agilent Technologies eArray web-based application (https://earray.chem.agilent.com/earray/). Briefly, Sbicolor release 79 coding sequences were downloaded from http://www.plantgdb.org/SbGDB/, based upon these 29289 CDS sequences, 28585 microarray probes (60 mer oligonucleotides) were designed. In addition, for 10 of the longest CDS, 10 tiling probes were also designed. These probes were randomly laid out onto the $4 \mathrm{X} 44 \mathrm{~K}$ microarray design format by eArray, along with default Agilent control probes (Agilent Technologies UK Ltd., Wokingham, Berkshire, UK), and 10 additional replicate probes of 100 randomly selected Sorghum CDSs.

\section{cRNA synthesis and labelling}

All products were obtained from Agilent Technologies UK Ltd. (Wokingham, Berkshire, UK) and used according to manufacturer's protocol unless stated otherwise. Total RNA was isolated using the RNeasy Mini Kit (Qiagen Sussex, UK). The integrity of the RNA was confirmed with analysis by the Agilent 2100 bioanalyzer (Palo Alto, CA) and the Agilent RNA 6000 Nano Kit (Cat no \# 50671511). RNA $(1 \mu \mathrm{g})$ was added to $1.2 \mu \mathrm{L}$ of $\mathrm{T} 7$ promoter primer and $5 \mu \mathrm{L}$ of a "spike-in" control and made to a total volume of $11.5 \mu \mathrm{L}$ with nuclease free water. The primer and template was denatured at $65^{\circ} \mathrm{C}$ for 10 mins. The One-Color Low RNA Input Linear Amplification Kit PLUS was used for the synthesis of cRNA as follows: $5 \times$ First Strand Buffer, DTT (to $10 \mathrm{mM}$ ), dNTP mix (to $0.5 \mathrm{mM}$ ), Moloney murine leukemia virus (MMLV) reverse transcriptase ( $1 \mu \mathrm{L}$ stock to $20 \mu \mathrm{L}$ reaction) and RNaseOut $(0.5 \mu \mathrm{L}$ of stock to $20 \mu \mathrm{L}$ reaction) were added to the denatured template. The cRNA was synthesized by incubation at $40^{\circ} \mathrm{C}$ for $2 \mathrm{~h}$ and then denaturation at $65^{\circ} \mathrm{C}$ for 15 minutes. Transcription Buffer $(\times 4)$, DTT (to $7.5 \mathrm{mM})$, NTP mix ( $8 \mu \mathrm{L}$ stock to $80 \mu \mathrm{L}$ reaction), PEG (to $4 \%$ ), RNaseOUT $(0.5 \mu \mathrm{L}$ to $80 \mu \mathrm{L})$, inorganic pyrophosphate $(0.6 \mu \mathrm{L}$ to $80 \mu \mathrm{L}$ reaction $)$, T7 RNA Polymerase $(0.8 \mu \mathrm{L}$ to $80 \mu \mathrm{L}$ reaction) and Cyanine 3-CTP (2.4 $\mu \mathrm{L}$ to $80 \mu \mathrm{L}$ reaction) were added. The synthesis of the cRNA was performed by incubation at $40^{\circ} \mathrm{C}$ for $2 \mathrm{~h}$.
The labelled cRNA was purified using the RNeasy Mini Kit (Qiagen, Sussex, UK) according to the manufacturer's protocol and quantified using a UV-VIS Spectrophotometer.

\section{Hybridization and washing of microarray slides}

The Agilent Hybridization Kit (catalog no. 5188-5242) was used: $2 \mu \mathrm{g}$ of the labelled sample RNA was added to $10 \mathrm{x}$ blocking Agent, $25 \times$ fragmentation buffer and nuclease free water to total volume of $55 \mu \mathrm{L}$. The RNA was fragmented by incubation at $60^{\circ} \mathrm{C}$ for $30 \mathrm{~min}$. Fragmentation was stopped by the addition of $55 \mu \mathrm{L} 2 \times \mathrm{GE}$ Hybridization Buffer HI-RPM. The hybridization was performed for $17 \mathrm{~h}$ at $65^{\circ} \mathrm{C}$ and $10 \mathrm{rpm}$. Slides were them washed for $1 \mathrm{~min}$ in Wash Solution 1; $1 \mathrm{~min}$ in Wash Solution 2 (prewarmed to $37^{\circ} \mathrm{C}$ ); and $20 \mathrm{~s}$ in acetonitrile. Slides were incubated for $30 \mathrm{~s}$ in Agilent Stabilization and Drying Solution (catalog no. 5185-5979). The slides were scanned with the Agilent G2505C Microarray Scanner System $(61 \times 21.6 \mathrm{~mm}$ scan region, $5 \mu \mathrm{m}$ single pass scanning mode, green dye channel). The accession number for the data series is GSE48205 (data is embargoed for 12 months, but can be accessed from: http://www.ncbi. nlm.nih.gov/geo/query/acc.cgi?token=rxmbxmaiogewe fw\&acc $=$ GSE48205).

\section{Bioinformatic analysis}

The Agilent Feature Extraction Software (v10.7) was used to extract data from scanned microarray images. The extracted data was analysed using GeneSpring GX 11 (Agilent Technologies, CA, USA). Agilent standard scenario normalizations for FE1-color arrays were applied to the data set. Controls, spots of poor quality and gene probes which were not present in all 3 reps in either the control or treatment samples were excluded from the analysis. This yielded approximately 21000 probes for each control vs. treatment comparison. From these selected genes those with a fold-change of $>2$ in all 3 reps of each treatment were selected. Gene Ontology term enrichment was determined using agriGO (http://bioinfo.cau.edu.cn/agriGO/) and redundant $\mathrm{GO}$ terms were removed using REVIGO (http://revigo.irb.hr/) (medium similarity). Promoter motif analysis was performed using the AMADEUS program (http://acgt.cs.tau.ac.il/amadeus/). Parameters selected for AMADEUS included: promoter length - $1000 \mathrm{bp}$ upstream to the transcription start site; motif length- 8 bp; 
motif reference database- TRANSFAC. A boot-strapping procedure was performed, which re-runs the entire algorithm on randomly selected gene sets, each with the same size as the real target set, and the lowest $p$-value from each run was recorded. A normal distribution was then fitted to these $p$-values and used to correct the $p$-values of the motifs discovered in the real target set. The corrected score is an estimate of the empirical probability that a motif with the same $p$-value (or lower) could be found in randomly selected gene sets. Fifty cycles of randomizations to obtain fixed p-values were used. The matrices obtained by AMADEUS for each motif were further processed by enoLOGOS (http://biodev.hgen.pitt.edu/cgi-bin/ enologos/enologos.cgi), a web-based tool that generates sequence logos.

\section{Realtime PCR}

Quantitative Real Time PCR was used to validate the gene expression data obtained by the microarrays as described previously [44]. cDNA was synthesised from Sorghum RNA using a high capacity cDNA reverse transcription kit (Applied Biosystems, California, USA). qPCR was carried out using an AB 7300 real time PCR system (Applied Biosystems California USA) and Go Taq qPCR master mix (Promega, Wisconsin,USA). Primers were designed using Primer3 (http://frodo.wi.mit.edu/) and synthesized by Invitrogen. Sequences used: Sb03g032380.1 Forward: 5' TCGGTACTGCTGCAAACAAG-3' and Sb03g032380.1 Reverse: 3'-CCGTGTTCATCACCTTCTCC-5'; Sb01g0 21320.1 Forward: 5'-GCGCGTCCGCTATATAATGT-3' and Sb01g021320.1 Reverse: 3'-CTTGCTGCTGTTGCT GTCTC5'; Sb02g038425.1 Forward: 5' -TGAGGAAGCTT GGGGTAATG-3' and Sb02g038425.1 Reverse: 3'-CCCA TAAGGACGCCAAAGTA-5'; Sb02g003260.1 Forward: 5' GATGGCTCGATTTCCTTGTC-3' and Sb02g003260.1 Reverse: 3'-GCCGATGATCTCCTTCTTCA-5'; Sb05g0 08020.1 Forward: 5' -AAGCGAGCAGTAAACCGTGT3' and Sb05g008020.1 Reverse: 3'- GTGATGAGAGGA GGGGAACA-5'; Sb05g017950.1 Forward: 5' - GGCAG CACTAGCAACAACAA-3' and Sb05g017950.1 Reverse: 3'-GGAAAGTAGCTTCCCCTTGG-5'. These genes were chosen as exemplar genes based on the fact that the microarray data showed that they are highly up-regulated ( $>2$ fold in all 3 reps) following only one of the treatment types i.e. heat, drought or combined stress. Sb03g038910.1 was identified from the microarray as unchanging following each treatment and was therefore used as an endogenous control with the following oligos: Sb03g038910.1 Forward: 5'-AGGTCCTGCTCCAGATCCTC-3' and Rev: 3'-AAAGGAGAGGGTAGCGGAAG-5'.

\section{Availability of supporting data}

The data set(s) supporting the results of this article are included in the article and are available in the GEO repository, (http://www.ncbi.nlm.nih.gov/geo/query/acc.cgi? token=rxmbxmaiogewefw\&ac;GSE48205).

\section{Additional file}

Additional file 1: Figure S1. The Fv/Fm (variable fluorescence/maximal fluorescence of Photosystem II) measured daily following water withdrawal. Table S1 - Genes differentially expressed in response to drought. Table S2 - Gene Ontology (GO) terms enriched $(p<0.05)$ in the genes differentially expressed in response to drought. Table $\mathbf{S 3}$ - Genes differentially expressed in response to drought only. Table S4 - Genes differentially expressed in response to heat. Table $\mathbf{S 5}$ - Gene Ontology $(G O)$ terms enriched $(p<0.05)$ in the genes differentially expressed in response to heat. Table $\mathbf{S 6}$ - Genes differentially expressed in response to heat only. Table S7 - Genes differentially expressed in response to combined heat and drought. Table S8 - Gene Ontology (GO) terms enriched $(p<0.05)$ in the genes differentially expressed in response to combined heat and drought. Table $\mathbf{S 9}$ - Genes differentially expressed in response to combined heat and drought only. Table S10 - Gene Ontology $(G O)$ terms enriched $(p<0.05)$ in the genes differentially expressed in response to combined heat and drought only. Table S11 - Genes differentially expressed in response to all 3 stress types.

Competing interests

The authors declare that they have no competing interests.

\section{Authors' contributions}

SJ participated in the design of the experiments, carried out the microarray processing and analysis and wrote the manuscript. AF and HF carried out the promoter motif analysis. FL contributed to the microarray processing. ARS participated in the design of the experiments. MRK participated in the design of the experiments, proof reading of the manuscript and in the overseeing of the work. All authors read and approved the final manuscript.

\section{Acknowledgements}

We would like to thank Yaron Orenstein from the School of Computer Science, Faculty of Exact Sciences, Tel Aviv University, for assistance in cis-element analysis with the AMADEUS program. We would also like to thank Tom Hash and Santosh Despande from ICRISAT, Petancheru, India for providing the seed material and the BBSRC for their CASE studentship.

\section{Author details}

${ }^{1}$ Durham Centre for Crop Improvement Technology, School of Biological and Biomedical Sciences, Durham University, South Road, DH1 3LE Durham, UK.

2Unilever, Colworth Science Park, MK44 1LQ Sharnbrook, Bedford, UK.

${ }^{3}$ Department of Molecular Biology and Ecology of Plants, Faculty of Life

Sciences, Tel Aviv University, 69978 Tel Aviv, Israel.

Received: 20 November 2013 Accepted: 27 May 2014

Published: 10 June 2014

\section{References}

1. Wang WX, Vinocur B, Altman A: Plant responses to drought, salinity and extreme temperatures: towards genetic engineering for stress tolerance. Planta 2003, 218(1):1-14.

2. Boyer JS: Plant productivity and environment. Science 1982, 218(4571):443-448.

3. Mittler R: Abiotic stress, the field environment and stress combination. Trends Plant Sci 2006, 11(1):15-19.

4. Craufurd PQ, Flower DJ, Peacock JM: Effect of heat and drought stress on Sorghum (Sorghum-bicolor). 1.Panicle development and leaf appearance. Exp Agric 1993, 29(1):61-76.

5. Savin R, Nicolas ME: Effects of short periods of drought and high temperature on grain growth and starch accumulation of two malting barley cultivars. Aust J Plant Physiol 1996, 23(2):201-210.

6. Machado S, Paulsen GM: Combined effects of drought and high temperature on water relations of wheat and sorghum. Plant Soil 2001, 233(2):179-187. 
7. Ahuja I, De Vos RCH, Bones AM, Hall RD: Plant molecular stress responses face climate change. Trends Plant Sci 2010, 15(12):664-674.

8. Bray EA: Plant responses to water deficit. Trends Plant Sci 1997, 2(2):48-54

9. Liu Q, Kasuga M, Sakuma Y, Abe H, Miura S, Yamaguchi-Shinozaki K, Shinozaki K. Two transcription factors, DREB1 and DREB2, with an EREBP/AP2 DNA binding domain separate two cellular signal transduction pathways in drought- and low-temperature-responsive gene expression, respectively, in Arabidopsis. Plant Cell 1998, 10(8):1391-1406.

10. Knight $H$, Knight MR: Abiotic stress signalling pathways: specificity and cross-talk. Trends Plant Sci 2001, 6(6):262-267.

11. Chen WQ, Provart NJ, Glazebrook J, Katagiri F, Chang HS, Eulgem T, Mauch F, Luan S, Zou GZ, Whitham SA, Budworth PR, Tao Y, Xie ZY, Chen X, Lam S, Kreps JA, Harper JF, Si-Ammour A, Mauch-Mani B, Heinlein M, Kobayashi K, Hohn T, Dangl JL, Wang X, Zhu T: Expression profile matrix of Arabidopsis transcription factor genes suggests their putative functions in response to environmental stresses. Plant Cell 2002, 14(3):559-574.

12. Qin D, Wu H, Peng H, Yao Y, Ni Z, Li Z, Zhou C, Sun Q: Heat stress-responsive transcriptome analysis in heat susceptible and tolerant wheat (Triticum aestivum L.) by using Wheat Genome Array. BMC Genomics 2008, 9:432.

13. Zhang Y, Mian MAR, Chekhovskiy K, So S, Kupfer D, Lai H, Roe BA: Differential gene expression in Festuca under heat stress conditions. J Exp Bot 2005, 56(413):897-907.

14. Kreps JA, Wu YJ, Chang HS, Zhu T, Wang X, Harper JF: Transcriptome changes for Arabidopsis in response to salt, osmotic, and cold stress. Plant Physiol 2002, 130(4):2129-2141.

15. Wang D, Pan Y, Zhao X, Zhu L, Fu B, Li Z: Genome-wide temporal-spatial gene expression profiling of drought responsiveness in rice. BMC Genomics 2011, 12:149.

16. Rizhsky L, Liang HJ, Mittler R: The combined effect of drought stress and heat shock on gene expression in tobacco. Plant Physiol 2002, 130(3):1143-1151.

17. Rizhsky L, Liang HJ, Shuman J, Shulaev V, Davletova S, Mittler R: When Defense pathways collide. The response of Arabidopsis to a combination of drought and heat stress. Plant Physiol 2004, 134(4):1683-1696.

18. Rampino P, Mita G, Fasano P, Borrelli GM, Aprile A, Dalessandro G, De Bellis L, Perrotta C: Novel durum wheat genes up-regulated in response to a combination of heat and drought stress. Plant Physiol Biochem 2012, 56:72-78.

19. Rosenow DT, Quisenberry JE, Wendt CW, Clark LE: Drought tolerant Sorghum and cotton germplasm. Agric Water Manag 1983, 7(1-3):207-222.

20. Paterson AH, Bowers JE, Bruggmann R, Dubchak I, Grimwood J, Gundlach H, Haberer G, Hellsten U, Mitros T, Poliakov A, Schmutz J, Spannagl M, Tang HB, Wang XY, Wicker T, Bharti AK, Chapman J, Feltus FA, Gowik U, Grigoriev IV, Lyons E, Maher CA, Martis M, Narechania A, Otillar RP, Penning BW, Salamov AA Wang Y, Zhang LF, Carpita NC, et al: The Sorghum bicolor genome and the diversification of grasses. Nature 2009, 457(7229):551-556.

21. Dugas DV, Monaco MK, Olsen A, Klein RR, Kumari S, Ware D, Klein PE: Functional annotation of the transcriptome of Sorghum bicolor in response to osmotic stress and abscisic acid. BMC Genomics 2011, 12:514

22. Buchanan CD, Lim SY, Salzman RA, Kagiampakis L, Morishige DT, Weers BD Klein RR, Pratt LH, Cordonnier-Pratt MM, Klein PE, Mullet JE: Sorghum bicolor's transcriptome response to dehydration, high salinity and ABA. Plant Mol Biol 2005, 58(5):699-720.

23. Maxwell K, Johnson GN: Chlorophyll fluorescence - a practical guide. J Exp Bot 2000, 51(345):659-668.

24. Oxborough K: Imaging of chlorophyll a fluorescence: theoretical and practical aspects of an emerging technique for the monitoring of photosynthetic performance. J Exp Bot 2004, 55(400):1195-1205.

25. Yoshiba Y, Kiyosue T, Nakashima K, YamaguchiShinozaki K, Shinozaki K: Regulation of levels of proline as an osmolyte in plants under water stress. Plant Cell Physiol 1997, 38(10):1095-1102.

26. Rubio F, Gassmann W, Schroeder Jl: Sodium-driven potassium uptake by the plant potassium transporter HKT1 and mutations conferring salt tolerance. Science 1995, 270(5242):1660-1663.

27. Huang D, Wu W, Abrams SR, Cutler AJ: The relationship of drought-related gene expression in Arabidopsis thaliana to hormonal and environmental factors. J Exp Bot 2008, 59(11):2991-3007.

28. Narusaka Y, Nakashima K, Shinwari ZK, Sakuma Y, Furihata T, Abe H, Narusaka M, Shinozaki K, Yamaguchi-Shinozaki K: Interaction between two cis-acting elements, ABRE and DRE, in ABA-dependent expression of
Arabidopsis rd29A gene in response to dehydration and high-salinity stresses. Plant J 2003, 34(2):137-148.

29. Beffagna N, Buffoli B, Busi C: Modulation of reactive oxygen species production during osmotic stress in Arabidopsis thaliana cultured cells: Involvement of the plasma membrane Ca2 +-ATPase and $\mathrm{H}+-$ ATPase. Plant Cell Physiol 2005, 46(8):1326-1339.

30. Akerfelt M, Morimoto Rl, Sistonen L: Heat shock factors: integrators of cell stress, development and lifespan. Nat Rev Mol Cell Biol 2010, 11(8):545-555

31. Gill SS, Tuteja N: Reactive oxygen species and antioxidant machinery in abiotic stress tolerance in crop plants. Plant Physiol Biochem 2010, 48(12):909-930.

32. Pastori GM, Foyer $\mathrm{CH}$ : Common components, networks, and pathways of cross-tolerance to stress. The central role of "redox" and abscisic acid-mediated controls. Plant Physiol 2002, 129(2):460-468.

33. Urao T, Yakubov B, Satoh R, Yamaguchi-Shinozaki K, Seki M, Hirayama T, Shinozaki K: A transmembrane hybrid-type histidine kinase in arabidopsis functions as an osmosensor. Plant Cell 1999, 11(9):1743-1754.

34. Mittler R, Finka A, Goloubinoff P: How do plants feel the heat? Trends Biochem Sci 2012, 37(3):118-125.

35. Ligterink W, Hirt H: Mitogen-activated protein (MAP) kinase pathways in plants: Versatile signaling tools. Int Rev Cytol Surv Cell Biol 2001, 201:209-275.

36. Whalley HJ, Knight MR: Calcium signatures are decoded by plants to give specific gene responses. New Phytol 2013, 197(3):690-693.

37. Heo WD, Lee SH, Kim MC, Kim JC, Chung WS, Chun HJ, Lee KJ, Park CY, Park HC, Choi JY, Cho MJ: Involvement of specific calmodulin isoforms in salicylic acid-independent activation of plant disease resistance responses. Proc Natl Acad Sci U S A 1999, 96(2):766-771.

38. Wu Y, Deng Z, Lai J, Zhang Y, Yang C, Yin B, Zhao Q, Zhang L, Li Y, Yang C, Xie Q: Dual function of Arabidopsis ATAF1 in abiotic and biotic stress responses. Cell Res 2009, 19(11):1279-1290.

39. Kasukabe Y, He LX, Nada K, Misawa S, Ihara I, Tachibana S: Overexpression of spermidine synthase enhances tolerance to multiple environmental stresses and up-regulates the expression of various stress regulated genes in transgenic Arabidopsis thaliana. Plant Cell Physiol 2004, 45(6):712-722.

40. Kusano T, Berberich T, Tateda C, Takahashi Y: Polyamines: essential factors for growth and survival. Planta 2008, 228(3):367-381.

41. Groppa MD, Tomaro ML, Benavides MP: Polyamines as protectors against cadmium or copper-induced oxidative damage in sunflower leaf discs. Plant Sci 2001, 161(3):481-488.

42. Zhang Y, Wu R, Qin G, Chen Z, Gu H, Qu L-J: Over-expression of WOX1 leads to defects in meristem development and polyamine homeostasis in Arabidopsis. J Integr Plant Biol 2011, 53(6):493-506.

43. Wood AJ, Goldsbrough PB: Characterization and expression of dehydrins in water-stressed Sorghum bicolor. Physiol Plant 1997, 99(1):144-152.

44. Moffat CS, Ingle RA, Wathugala DL, Saunders NJ, Knight H, Knight MR: ERF5 and ERF6 play redundant roles as positive regulators of JA/Et-mediated defense against Botrytis cinerea in Arabidopsis. PLoS One 2012, 7:4.

doi:10.1186/1471-2164-15-456

Cite this article as: Johnson et al:: Transcriptomic analysis of Sorghum bicolor responding to combined heat and drought stress. BMC Genomics 2014 15:456.

\section{Submit your next manuscript to BioMed Central and take full advantage of:}

- Convenient online submission

- Thorough peer review

- No space constraints or color figure charges

- Immediate publication on acceptance

- Inclusion in PubMed, CAS, Scopus and Google Scholar

- Research which is freely available for redistribution 